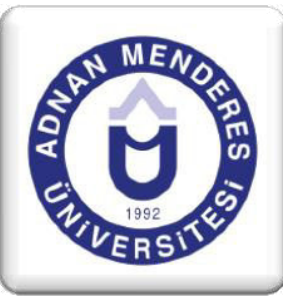

\title{
Büyükşehir: Tekirdağ
}

\section{Metropolitan City: Tekirdağ}

\section{Özet}

Tekirdağ ülkemizin önemli turizm ve sanayi kentlerinden birisidir. Artan nüfus ve ülkenin gelişmişlik sırasındaki yeri ile 2012 yılında büyükşehir statüsüne geçmiştir. Hızlı büyüyen çoğu kentimizde olduğu gibi Tekirdağ ili'nde de hızlı kentleşmenin sebep olduğu olumsuzluklar bulunmaktadır. Büyükşehir olma süreci ile fiziki ve idari yapılanmasını yenileyen kentte bu olumsuzlukların artarak devam edeceği düşünülmektedir. Bu amaçla, yapılan kentsel planlama ve tasarım çalışmalarının sürdürülebilir kent kavramına uygun yapılması oldukça önemlidir. Bu çalışma kapsamında, Tekirdağ'ın doğal, kültürel ve sosyo-ekonomik verileri ortaya konularak büyükşehir olma süreci ve sonrası değerlendirmeler yapılmıştır.

Anahtar kelimeler: Tekirdağ, Mekansal Planlama, Büyükşehir Belediye Kanunu

\section{Abstract}

*Doç. Dr.

Tekirdağ is one of our country's major tourism and industrial city. During the growing population and the country's development due to the location in 2012 was changed to metropolitan status. Most of the fastest growing in our city as well as in the province of Tekirdag, the negative effects are caused by rapid urbanization. Metropolitan process of being renewed with the physical and administrative structuring of this negativity in the city is expected to continue to increase. For this purpose, the urban planning and design work to be done according to the concept of sustainable cities is very important. In this study, Tekirdağ's natural, cultural and socio-economic data, putting forward the process of being metropolitan and after assessments have been made.

Keywords: Tekirdağ, Spatial Planning, Metropolitan Municipality Law

Murat ÖZYAVUZ*

Elif Ebru ŞISSMAN**
Namık Kemal Üniversitesi

Tasarım ve Mimarlık Fakültesi

Peyzaj Mimarlığı Bölümü

${ }^{* *}$ Doç. Dr.

Namık Kemal Üniversitesi

Tasarım ve Mimarlık

Fakültesi

Peyzaj Mimarlığı Bölümü 


\section{GİRIŞ}

12/11/2012 tarihinde onaylanarak resmi gazetede yayınlanan "On Dört İlde Büyükşehir Belediyesi Ve Yirmi Yedi İlçe Kurulması İle Bazı Kanun Ve Kanun Hükmünde Kararnamelerde Değişiklik Yapılmasına Dair Kanun" ile 14 ilimiz büyükşsehir statüsü almıştır. Bu kanun gereği büyükşehirlerin fiziki ve idari yapılanmalarını yeniden oluşturmaları gerekmektedir. Tekirdağ İli de bu kanun ile büyükşehir statüsü kazanmıştır. Kanunda yer alan maddeler gereği, bu illere bağlı ilçelerin mülki sınırları içerisinde yer alan köy ve belde belediyelerinin tüzel kişiliği kaldırılmış, köyler mahalle olarak, belediyeler ise belde ismiyle tek mahalle olarak bağlı bulundukları ilçenin belediyesine katılmıştır. Ayrıca bu illerdeki il özel idarelerinin tüzel kişiliği kaldırılmıştır. Aynı kanun kapsamında Tekirdağ'da mevcutta bulunan 9 ilçe sayısı yeni ilçe belediyeleri ile birlikte 11'e yükseltilmiştir (Resmi Gazete, 2012: 11741). Bu büyükşehir belediyelerinin idari yapılması ve yönetimi ise 10.07.2004 tarihinde kabul edilen "Büyükşsehir Belediyesi Kanunu'na" göre yapılacaktır. Bu kapsamda, bu makalede son yasa ile büyükşehir statüsü kazanan Tekirdağ kentinin genel tanıtımı (yerleşim, nüfus vb.), kentin mekânsal gelişimi, belediyeciliğin tarihi gelişimi, kentin büyükşehir olma süreci ve sonrasında yapılacak idari yapılanmalar ile olası sorunlar ortaya konularak çözüm önerileri geliştirilmiştir.

\section{COĞRAFİ ÖZELLİKLER}

Tekirdağ, coğrafi alan itibariyle Marmara Bölgesindeki 11 ilin üçünden küçük, komşusu Kırklareli ile aynı büyüklüğe sahiptir. Yüzölçümü itibariyle bölgede 4. sırada yer alan Tekirdăg, Marmara bölgesinin \% 8.6'sın1, Türkiye topraklarının ise yaklaşık \% 0,8'ini kaplamaktadır. Gelişmiş bir ulaşım ağ 1 içinde yer alan il, 3 önemli karayolu, büyük bir diş ticaret limanı ve İstanbul-Avrupa demiryoluyla İstanbul metropolüne ve komşu Avrupa ülkelerine bağlanmış bulunmaktadır. Tekirdağ ilinin arazi varlı̆̆ incelendiğinde en büyük orana $(\% 58,43)$ tarım alanlarının sahip olduğu görülmektedir (Çizelge 1).

Çizelge 1. Arazi Varlı̆̆ı Dağılımı (TÜiK, 2011a)

\begin{tabular}{|l|l|l|}
\hline Kullanılış Biçimi & Alan (da) & Oranı (\%) \\
\hline İ̧̧lenen Tarım Alanı & 3.574 .080 & 58,43 \\
\hline Çayır-Mera Alanı & 325.793 & 5,33 \\
\hline Ormanlık Alan & 1.042 .535 & 17,04 \\
\hline Tarım Dışı Arazi & 1.174 .125 & 19,20 \\
\hline Toplam & 6.116 .533 & 100,00 \\
\hline
\end{tabular}

Tekirdağ İli, Türkiye'nin kuzeybatısında, Marmara Denizi ve Karadeniz'e kıyısı olan bir ilimizdir. Doğuda İstanbul'a bağlı Silivri ve Çatalca İlçeleri, kuzeyde Kırklareli’ne bağlı Vize, Lüleburgaz, Babaeski ve Pehlivanköy İlçeleri, batıda ise Edirne İline bağlı Uzunköprü ve Keşan İlçeleri ile çevrili olan İl'in, kuzeydoğuda Karadeniz'e 1,5 km'lik bir kıyısı bulunmaktadır. Ayrıca, Trakya Bölgesinin güneyinde yer alan Tekirdağ'ın Marmara Denizine $133 \mathrm{~km}$. Karadeniz'e de $2.5 \mathrm{~km}$. uzunluğunda kıyıları bulunmaktadır. Komşu olduğu illerden Edirne'ye 141 km. Çanakkale'ye 194 km. İstanbul'a 131 km. ve Kırklareli'ne 122 km. uzaklıktadır. Bununla birlikte, Tekirdağ İli, Edirne ve Kırklareli illeri ile birlikte, Türkiye İstatistiki Bölge Birimleri Sınıflandırması (IBBSS)'ye göre TR 21 Tekirdağ Alt Bölgesi olarak adlandırılan Düzey 2 bölgesini oluşturmaktadır.

Balkan yarımadasının güneydoğu kesiminde yer alan Trakya Bölgesinde farklı morfolojik üniteler vardır. Tekirdağ Bölgesinde bu morfolojik ünitelerden dağlık olanları kuzeydeki Istranca (Yıldız) dağlık kütlesi ile güneydeki Ganos (Işık) ve Koru dağlarıdır. Bu iki dağlık arazi arasında, Ergene Irmağının kolları ile yarılmış, hafif, orta ve bazen dik eğimli peneplen arazileri ile güney ve yer yer orta kısımlarda yer alan yüksek tepelik ve eğimli yamaç araziler bulunmaktadır. Yıl içerisinde düşen düşük yağış miktarı, toprak 
özellikleri ve diğer koşullar nedeniyle Tekirdağ'da pek büyük bir akarsu yoktur. İldeki küçük akarsuların yatakları mevsimlere göre değişir. Yazın suları azalan, hatta kuruyan bu akarsular kışın yükselir. Zaman zamanda taşar. İldeki küçük akarsu ve derelerin oluşturduğu iki ana havzadan bahsedilebilir. Bu havzalar Ergene ve Marmara Havzasıdır.

Trakya; kuzeyinde ve güneyindeki nemli deniz ikliminin etkisinin altında çeşitli orman topraklarının hakim olduğu, iç Trakya’ya ise kurak bozkır özelliklerine uygun orman, otlak ve genellikle tarım alanlarının yaygın olarak bulunduğu, bu sebeple de biyolojik çeşitlilik bakımından çok zengin bir ekolojik sistemler birliğidir.

Tekirdağ'ın kuzeyinde Saray İlçesine doğru uzanan Istranca kütlesinin kuzey yamaçları daha fazla yağış alması nedeniyle kayın ormanları ile kaplıdır. Bu kesimde ormanaltı örtüsünü orman gülleri oluşturur. Güney yamaçlara ve daha güneye doğru inildikçe, yağışın azalmasına bağlı olarak, kayının yerini meşe ve gürgenin aldığı görülür. Bazı kesimlerde ise az da olsa kızılağaç, karaağaç ve yer yerde çam türlerine rastlanmaktadır. Tipik bitkiler Akdeniz iklimine has makiler, bağlar, meyve bahçeleri ve zeytinliklerdir. Ergene havzasına doğru inildiğinde ise yerleşim alanları yakınlarında seyrek olarak meşe, gürgen, karaçalı ve karaağaç toplulukları göze çarpmaktadır. Bu küçük ağaç toplulukları, Trakya'nın iç kesimlerinin step alanı olmadığının bir kanıtıdır. Trakya bölgesi, tarım arazisi kazanmak amacıyla ormanların tahribi sonucu (Antropojen step), bugünkü step arazisi görünümünü kazanmıştır. Bu kısımda yer alan taban arazilerde ve vadilerde kavak ve söğüt türleri yaygındır. Güneydeki Ganos Dağlarının kuzey yamaçlarında gürgen, meşe, ıhlamur ağaçları ve sık bir ormanaltı örtüsü hakimken, güney yamaçlarda yağışın azalması nedeniyle kuru ormanlar ve maki toplulukları yer almaktadır. Koru dağlarında ise meşe ve kızılçam ormanları ile maki toplulukları hakim durumdadır.

Tekirdağ'ın Marmara kıyılarında yağış bakımından Akdeniz iklimi egemendir. Kıyı şeridinde yazlar sıcak, kışlar 1lık geçer. Buralarda tek fark kışın kar yağmasıdır. Yörede zaman zaman esen kuzey rüzgârları, ısının düşmesine neden olur. Kuzeye paralel uzanan Tekir dağları da kıyı kesimini Balkanlardan gelen soğuk hava kütlesine karşı korur. İlin iç bölgelerinde ise karasal iklim egemendir. Yazlar sıcak ve kurak, kışlar ise soğuk ve yağışlıdır. Buralar kış boyunca esen kuzey rüzgârlarının etkisi altında kalır.

\section{ULAŞIM}

Tekirdağ ulaşım açısından ülkemizin şanslı illerinden birisidir. Tekirdağ sınırları içerisinden Avrupa transit yolları geçmektedir. İstanbul-Edirne-Avrupa demiryolu il sınırları içinden geçer. Günümüzde büyük bir metropol durumuna gelen İstanbul'a yakınlığı Tekirdağ için büyük avantajlar sağlamaktadır.

Türkiye'nin en yoğun ithalat ve ihracatının yapıldığı İstanbul ile Avrupa arası bağlantı sağlayan D-100 ve D-110 karayolu ile TEM otoyolu il sınırları içerisinden geçmektedir. D-100 İpsala sınır kapısı ile Yunanistan'a, D-110 ve TEM otoyolu ile de Kapıkule sınır kapısından Bulgaristan'a ulaşılmaktadır. Tekirdağ komşu illerden İstanbul'a 136 km, Edirne'ye 130 km, Kırklareli'ne 118 km'dir. Bunun yanında ilçeleri Hayrabolu'ya 55 km, Çorlu'ya 37 km, Çerkezköy’e 60 km, Malkara'ya 59 km, Marmara Ereğlisi'ne 38 km, Muratlı'ya 24 km, Saray'a 77 km, Şarköy’e 81 km uzaklıktadır. Komşu ülkelerden Yunanistan'a 125 km, Bulgaristan’a ise sınırı 150 km dir (Karayolları Genel Müdürlüğü, 2013).

Tekirdağ'ın Marmara Denizi’ne 135 km kıyısı olması ve çeşitli amaçlarla kullanılan birçok iskeleye sahip olması Tekirdağ'dan yapılan deniz ticaretini artırmaktadır. Tekirdağ şu an aktif olarak kullanılan iki limana sahiptir. Diğer önemli bir limanı ise tamamlanma aşamasındadır.

Tekirdağ Limanı; Haydarpaşa Limanına 70 mil, Bandırma limanına 53 mil, Ambarlı limanına 55 mil, Gemport limanına 80 mil, Varna limanına 212 mil, Köstence limanına 262 mil, İstanbul Boğazına 69 mil, Çanakkale Boğazına 54 mil uzaklığındadır. Tekirdağ Limanı, İstanbul Metropolü’ndeki ulaşımdan ileri gelen yığılmaları azaltabilecek, dengeli bir gelişmeyi ve ulaşımı sağlayacak yeni bir liman bölgesi potansiyeline sahiptir. Liman'da eski ve yeni iskele olarak iki iskele bulunmaktadır. İşletme; açık ve kapalı alan olarak $23.998 \mathrm{~m}^{2}$ toplam alana sahiptir. Eski iskelenin iskele boyu $309 \mathrm{~m}$, iskele genişliği $1.805 \mathrm{~m}$ 'dir ve 5 adet yanaşma yeri bulunmaktadır. Derinliği $-3.5 \mathrm{~m}$ ve geri kalan saha dahil alanı $5.632 \mathrm{~m}^{2}$ dir. Yeni iskelenin boyu ise $342,7 \mathrm{~m}$ ve iskele genişliği $2.055 \mathrm{~m}$ ' dir ve 2 adet yanaşma yeri bulunmaktadır. Derinliği - 
2,4 $\mathrm{m}$ ile $10 \mathrm{~m}$ arasında değişmektedir. Yeni iskelenin giriş kısmı dahil alanı $7.805 \mathrm{~m}^{2}$ 'dir. Ro-Ro rıhtımının boyu $621 \mathrm{~m}$ ve derinliği -4 m'dir. Bunun yanında işletme tarafından Ro-Ro amacıyla kullanılan rihtım ve iskelelerin yanaşma yerleri toplamı $1.143 \mathrm{~m}$ 'dir. TMO iskelesinin boyu $621 \mathrm{~m}$ ve derinliği $-4 \mathrm{~m}$ ile $-12 \mathrm{~m}$ arasında değişmektedir. Limanın gemi kabul kapasitesi toplam olarak 1.600 gemi/yıldır. Bunların 1.200 adedi 2 adet iskele ve Ro-Ro rıhtımı, 400 adedi ise TMO ve TEKEL iskelelerine yanaşmaktadır. Eşya cinslerine göre toplam yükleme ve boşaltma kapasitesi 2.600.000 ton/yıl, dökme katı olarak 1.200.000 ton/yıl ve dökme sıv1 olarak 50.000 ton/yıldır. Limanın toplam ambarlama kapasitesi ise 1.020 .000 ton/yil'dir.

Akport Limanı; 205 m boyunda, gemi yanaşması yeri 140 m olan (iki büyük ve iki küçük gemi) bir iskeleye sahiptir. Tekirdağ ili içindeki ikinci iskelesi $399 \mathrm{~m}$ uzunluğundadır. Bunun $212 \mathrm{~m}$ 'si $8 \mathrm{~m}$ genişliğinde giriş yolu mahiyetindedir. 187 m'si (L) seklinde olup $18 \mathrm{~m}$ genişliğindedir. Buraya iki taraflı vapurlar yanaşarak yük alma ve boşaltma işlemi yapabilmektedir. Limanla beraber Tekirdağ sahili iskele hüviyetli 8 adet küçük tonajlı gemi iskelesinden oluşmaktadır. Akport Tekirdağ Limanı'nda uzun yıllardan beri yapılmayan Ro-Ro seferlerine Tekirdağ-Trieste seferleri ile 1998 yılında başlanmış ve 2001 yılına kadar devam etmiştir. Bununla beraber Türkiye'de ilk defa Marmara Denizi'nin içinde Tekirdağ- Bandırma, Tekirdağ-Gemlik limanları arasında Ro-Ro seferlerine başlanmıştır. Bu seferler hergün yapılmaktadır ve ulusal ve uluslararası yük vagonları servis edilmektedir. Akport Tekirdağ Limanı'nın TEM otoyol bağlantısına uzaklığı 53 km'dir. Tekirdağ- Muratlı arasındaki yol genişletme çalışmaları 2006 yılının başında başlamış ve yılsonunda tamamlanmıştır. Diğer taraftan 2007 yılında Tekirdağ-Kınalı karayolu geliş/gidiş olarak çift şeride çıkarılmış, Tekirdağ-İstanbul karayolu bağlantısı kolaylaştırılmıştır. Akport Tekirdağ Limanı'nın, en yakın tren istasyonu olan Muratlı Tren İstasyonu'na uzaklığı 25 km'dir. Tekirdağ - Muratlı arasındaki demiryolu projesinin devam eden uygulaması da tamamlandıktan sonra Akport Limanı'nın demiryolu bağlantısı sağlanmış olacaktır. Akport Tekirdağ Limanı, Ambarlı ve Haydarpaşa Limanları ile rekabet içindedir. Hizmet alanı Batı Marmara Bölgesi ile Balkanlardır. Yakın gelecekte İtalya'nın Trieste Limanı'ndan Tekirdağ-Trieste uluslararası Ro-Ro hattına başlanması planlanmaktadır. Ayrıca özel antrepo hizmeti veren Tekirdağ Akport Limanı, bu hizmetin verilebildiği 3 ya da 4 limandan bir tanesidir.

Asyaport Limanı; Türkiye'nin ilk transit konteyner limanı (Hubport) olan Asyaport, Barbaros/Tekirdağ'da 2014 yılında faaliyete geçecektir. 20 metre derinliğe kadar toplam 2000 metre rıhtımı ve yıllık 2,5 milyon TEU'ya varacak kapasitesi ile dünya ölçeğinde bir liman konumundadır. Asyaport Limanı'nda 11 adet 24 yan siraya kadar hizmet verebilecek kapasitede rihtım vinci (Ship-to-ShoreGantry Crane) ile 33 adet lastik tekerlekli saha vinci (RubberTyreGantry Crane) çevreci bir yaklaşımla, tamamen elektrik enerjisi ile çalışacak şekilde tasarlanmıştır. Asyaport, denizyolu, karayolu ve demiryolu bağlantıları ile bölgesinde bir lojistik merkez olarak gelişen Tekirdağ'ın iş ve çalışma yaşamına 1200 kişilik isdihdam kapasitesi ile büyük bir katkı sağlayacaktır.

Tekirdağ-Çorlu Uluslararası havaalanı, Çorlu'ya $15 \mathrm{~km}$ uzaklıkta, 36 hektar arazi üzerinde $10.434 \mathrm{~m}^{2}$ kapalı alanı, 11 adet uçak park sahası, 2 adet $3 \mathrm{~km}$ uzunluğunda pisti ve ILS sistemine sahip olup yıllık yolcu kapasitesi 600.000 ve yıllık uçak kapasitesi 10.000'dir.Havaalanı yanında 1500 da alanda Türkiye'nin ilk "kargo köyü" kuruluş çalışmaları devam etmektedir.

\section{NÜFUS}

İçişleri Bakanlığı Nüfus ve Vatandaşlık İşleri Genel Müdürlüğü (NVİGM) tarafından güncellenen Adrese Dayalı Nüfus Kayıt Sistemi'nden (ADNKS) alınan bilgilere göre Tekirdağ'ın yıllara göre nüfusu Çizelge 2'de verilmiştir.

Çizelge 2.Tekirdağ'’n Yıllara Göre Nüfusu (TÜİK, 2013a)

\begin{tabular}{|l|l|l|l|l|l|l|l|}
\hline Nüfus & 2007 & 2008 & 2009 & 2010 & 2011 & 2012 & 2013 \\
\hline
\end{tabular}




\begin{tabular}{|l|l|l|l|l|l|l|l|}
\hline Tekirdağ & 728396 & 770772 & 783310 & 798109 & 829873 & 852321 & 874475 \\
\hline
\end{tabular}

2013 yılında Tekirdağ'da ikamet eden nüfus bir önceki yıla göre 22154 kişi artarak 874475 kişi olmuştur. Tekirdağ nüfusunun \% 51,5'ini (450 149 kişi) erkekler, \%48,5'ini (424 326 kişi) ise kadınlar oluşturmaktadır. 2013 yılında Tekirdağ'ın yıllık nüfus artış hızı \%o 25,7 olarak gerçekleşmiştir. 2012 yılında \%o 26,7 olan Tekirdağ' 'n yıllık nüfus artış hızı 2013 yılında \%o 25,7'ye düşmüştür. Tekirdağ \%o 25,7 nüfus artış hızı ile nüfus artış hızı sıralamasına göre 81 il arasından 6. sırada yer almıştır. Tekirdağ, Ankara ve Antalya en fazla göç alan iller olurken, Çankırı, Yozgat ve Tokat en fazla göç veren illerdir. Ayrıca illerin nüfus büyüklüğü sıralamasına göre Tekirdağ 874475 kişilik nüfusla 23'üncü sırada yer almaktadır (Çizelge $3)$.

\begin{tabular}{|c|c|c|c|c|c|}
\hline Yillar & Toplam nüfus & Aldığı göç & Verdiği göç & Net göç & $\begin{array}{l}\text { Net göç hızı } \\
(\%)\end{array}$ \\
\hline 1975-1980 & 296239 & 28421 & 23572 & 4849 & 16,5 \\
\hline 1980-1985 & 335542 & 31066 & 27628 & 3438 & 10,3 \\
\hline 1985-1990 & 392512 & 49734 & 31827 & 17907 & 46,7 \\
\hline $1995-2000$ & 555916 & 88618 & 37283 & 51335 & 96,8 \\
\hline 2007-2008 & 770772 & 47534 & 22373 & 25161 & 33,2 \\
\hline 2008-2009 & 783310 & 37655 & 29066 & 8589 & 11,0 \\
\hline 2009-2010 & 798109 & 41307 & 29433 & 11874 & 15,0 \\
\hline 2010-2011 & 829873 & 42265 & 28620 & 13645 & 16,6 \\
\hline 2011-2012 & 852321 & 42155 & 28042 & 14113 & 16,7 \\
\hline $2012-2013$ & 874475 & 45313 & 31681 & 13.632 & 15,7 \\
\hline
\end{tabular}

Yaş gruplarına bakıldığında, Tekirdağ nüfusunun yarısı 32,5 yaşından küçüktür. Tekirdağ 15-64 yaş grubunda bulunan çalışma çağındaki nüfus oranı 2012 yılında \%71,3 (607 958 kişi) iken bu oran 2013 yılında \%71,3 (623 466 kişi) olarak sabit kalmıştır. 0-14 yaş grubundaki nüfusun oranı ise 2012 yılında \%21,4 (182 013 kişi) iken 0,2 puan gerileyerek \%21,2 (185 681 kişi) olarak gerçekleşmiştir. 65 ve daha yukarı yaştaki nüfusun oranı 2012 yılında \%7,3 (62 350 kişi) iken 0,2 puanlık artışla \% 7,5 'e (65 328 kişi) yükselmiştir.

Nüfus yoğunluğu olarak ifade edilen "bir kilometrekareye düşen kişi sayısı" Türkiye genelinde 100 kişidir. Bu sayı Tekirdağ'da 139 kişi iken, İstanbul 2.725 kişi ile nüfus yoğunluğunun en fazla olduğu ildir. Tekirdağ, nüfus yoğunluğu en yüksek iller sıralamasına göre 15. sırada yer almıştır.

\section{EKONOMI}

Tekirdağ, geçmişten günümüze kadar önemli bir tarım ve turizm merkezi olmuştur. 2000'li y1llarda ise tarım ve sanayi, Tekirdağ ekonomisindeki temel sektörleri oluşturmaktadır. Göz ardı edilen turizm ve devlet politikaları (kredi ve teşvikler) paralelinde giderek zayıflayan tarım sektörleri, yerini yine sanayiyi geliştirmeye yönelik devlet politikaları paralelinde sanayi sektörüne ve ortaya çıkan ekonomik yapının ivmesiyle de hizmet sektörüne bırakmıştır. 
TÜİK 2008 verilerine göre, Türkiye genelinde kişi başı GSKD 9.384 USD’dir. Tekirdağ, Edirne ve Kırklareli illerini içinde barındıran TR21 Trakya Bölgesinde ise bu değer, 12.243 USD'dir ve Türkiye genelinde en yüksek 5. bölgedir. Diğer taraftan, 2010 yılında Türkiye genelinde işsizlik oranı \%11,9 iken, Tekirdağ ilinde bu oran \%9,6'da kalmıştır.

2000 yılı verilerine göre Tekirdağ' da sektörel dağılım tarım için \%38,8, hizmetler sektörü için \%35, sanayi sektörü için de \%26,2 olarak göze çarpmaktadır. Bu dünya standartlarıyla benzeşen yönlerinin yanı sıra, hizmetler sektöründe gelişime ihtiyaç olduğunu gösteren bir veridir. 2023 öngörüleri dikkate alındığında sektörler arası dağılım şu şekilde ifade edilebilir: Tarım \%18, hizmetler \%51 ve sanayi \%31. Bu oranlar 1/100.000'lik Trakya Alt Bölgesi Ergene Havzası Revizyon Çevre Düzeni Planı'nda bulunan rakamları yansitmaktadir.

Tekirdağ, gelişmiş sanayisi ve uluslararası firmaların içinde bulunduğu üretim tesisleriyle göz doldurmaktadır. Tekirdağ toplam işletmeler içerisinde \%2'lik payla sanayisi gelişmiş onuncu il olarak üst sıralarda yer almaktadır. Marmara Bölgesi dikkate alındığında \%3'lük sanayi payıyla İstanbul, Bursa ve Kocaeli'nden sonra dördüncü en büyük olarak dikkat çekmektedir. Ülke genelinde tekstilin \%10'u, margarinin \%25'i, rafine ayçiçeği yağının \%20'si, kağıt ve ambalajın \%40'1, işlenmiş derinin \%37'si bu ilden karşılanmaktadır. İldeki kuruluşlar kendi sektörlerinde marka konumda olan büyük işletmelerdir. Özellikle son yirmi y1l içerisindeki gelişmelerle birlikte Tekirdağ, adeta Türkiye'nin tekstil, gıda, toprak, beyaz eşya gibi alanlarda üretim üssü haline gelmiştir.

İl genelinde, Merkez, Çorlu, Çerkezköy, Hayrabolu ve Malkara'da olmak üzere 5 adet sanayi ve ticaret odası bulunmaktadır. Bu odaların 2012 yılı kayıtlı üye sayısı 14.503'tür. Merkez, Çorlu, Hayrabolu ve Malkara'da bulunan dört adet ticaret borsasının da 392 faal üyesi bulunmaktadır. İl genelinde Esnaf ve Sanatkarlar Odalarına kayıtlı 25.629 üye bulunmaktadır.

2011 verileri 1şığında Bilim, Sanayi ve Teknoloji Bakanlığı tarafında hazırlanan il durum raporuna göre ilde kayıtlı çalışan sayısı 105.798'tir. Bu çalışanların \%37'si tekstilde; \%14'ü ise giyim eşyası üreten tesislerde istihdam edilmektedir. Tekirdağ'da yıllara göre ihracat ve ithalat değerleri Çizelge 4' de verilmiştir.

Çizelge 4. Tekirdağ'da Yıl Bazlı İhracat Ve İthalat Değerleri (Bilim, Sanayi Ve Teknoloji Bakanlığı, 2012: 403)

\begin{tabular}{|l|l|l|ll|l|}
\hline Yıl & $\begin{array}{l}\text { İhracatçı Firma } \\
\text { Sayısı }\end{array}$ & $\begin{array}{l}\text { İhracat Değeri } \\
(\mathbf{1 . 0 0 0} \text { USD) }\end{array}$ & $\begin{array}{l}\text { İthalatçı Firma } \\
\text { Sayıs }\end{array}$ & $\begin{array}{l}\text { İthalat Değeri } \\
(\mathbf{1 . 0 0 0} \text { USD) }\end{array}$ \\
\hline $\mathbf{2 0 0 8}$ & 292 & 526.384 & 320 & 593.914 \\
\hline $\mathbf{2 0 0 9}$ & 287 & 483.240 & 310 & 473.826 \\
\hline $\mathbf{2 0 1 0}$ & 293 & 546.461 & 346 & 603.027 \\
\hline $\mathbf{2 0 1 1}$ & 323 & 655.086 & 421 & 779.232 \\
\hline
\end{tabular}

Tekirdağ, mevcut 4 organize sanayi bölgesi (OSB) ve kurulma aşamasında olan 8 1slah OSB ile önemli bir sanayi potansiyeline sahiptir. Büyüklüğü 5.000 ha olan organize sanayi bölgelerinde yaklaş1k 1.000 işletme faaliyet göstermekte ve 90.000 'e yakın kişi çalışmaktadır. Tekirdağ'da ayrıca 1 tane serbest bölge bulunmaktadır. Tekirdağ'ın Çorlu ilçesinde kurulan Avrupa Serbest Bölgesi (ASB); stratejik konumu itibariyle Türk ihracatçısının, özellikle Avrupa ile olan ticari ilişkilerinde merkezi bir rol üstlenmiştir. İl genelinde 8 küçük sanayi sitesi (KSS) bulunmaktadır. KSS'lerinin toplam büyüklüğü 1.639 da olup, bu alanlarda 2.340 firma faaliyet göstermektedir. Tekirdağ'da yer alan KSS'lerde 4.967 kişi istihdam edilmektedir.

Tekirdağ İlinde kişi başına ithalat ve ihracat değerlerinin Türkiye geneline göre karşılaştırması Çizelge 5' te verilmiştir. 
Çizelge 5. 2011 Yılı Türkiye Ve Tekirdağ Dış Ticaret Verileri (TÜİK, 2011b)

\begin{tabular}{|c|c|c|c|c|}
\hline & İthalat Değeri (000 \$) & İhracat Değeri (000 \$) & Kişi başına ithalat (\$) & $\begin{array}{c}\text { Kişi başına ihracat } \\
\text { (\$) }\end{array}$ \\
\hline Türkiye & 240.841 .676 & 134.906 .869 & 3.223 & 1.805 \\
\hline Tekirdağ & 779.629 & 655.580 & 939 & 790 \\
\hline
\end{tabular}

İthalat ve ihracat rakamları vergi kimlik numaralarının kayıtlı olduğu illere göre hesaplandığı için Tekirdağ' daki kişi başına ithalat ve ihracat değerleri gerçekleşenden daha düşük gözükmektedir. Diğer bir deyişle Tekirdağ'da faaliyet gösteren ve üretim yapan birçok firma, vergilerini İstanbul'da ödediği için, kayıtlarda İstanbul gözüken rakamların bir kısmı aslında Tekirdağ'a aittir. Tekirdağ gümrüklerinde 2011 yılında 1.588.203.000 USD ihracat ve 4.830.130.000 USD ithalat gerçekleşmiştir. Tekirdağ'da 2011 yılındaki brüt vergi tahakkuku 3.757.081.039 TL olmuştur. 2011 yılı için bütün iller arasında toplam vergi tahakkukundaki sıralama incelendiğinde, Tekirdağ'ın 9. sırada yer aldığı görülmektedir.

\section{GELISŞMIŞLIKK}

"Gelişmişlik Sıralaması Araştırmast-2011" çalışmasına göre, Tekirdağ, 81 il içinde 9. sırada yer almaktadır (Çizelge 6). Araştırmada, Tekirdağ ikinci kademede yer almaktadır. Bu kademede yer alan 13 il arasında Edirne ve Kırklareli dahil olmak üzere 1. sırada yer almaktadır. Tekirdağ işgücü göstergeleri itibarıyla hem etkisi altında bulunduğu İstanbul'dan hem de ülke ortalamalarından daha yüksek değerlere sahiptir. İşgücüne katılma oranı ülke genelinde yüzde 49 düzeyinde iken, Tekirdağ'da bu oran yüzde 55 seviyesindedir. İmalat sanayii istihdamının sigortalı istihdam içerisindeki oranında Tekirdağ tüm iller içerisinde ilk sırada gelmektedir. Bu değişken itibarıyla ülke ortalaması yüzde 28,6 iken Tekirdağ'da bu oran yüzde 57,6'dır.

Kalkınma Bakanlığı tarafindan 2011 yılında yapılan illerin ve bölgelerin sosyo-ekonomik gelişmişlik sıralaması araştırmasında, Tekirdağ iller arasında 9. sırada ve 2. derece gelişmiş iller kategorisinde yer almıştır. Türkiye'de bulunan imalat sanayii işyerlerinin yüzde 31'i İstanbul'da bulunmaktadır. İzmir, Ankara, Bursa ve Konya diğer önemli imalat sanayii merkezleridir. Kişi başına düşen imalat sanayii elektrik tüketiminde ise Kocaeli, Çanakkale ve Tekirdağ illeri ilk üç sırayı paylaşmaktadır.

Aynı araştırmada sağlık göstergeleri incelendiğinde, Tekirdağ sağlık sektöründe gelişmişlik açısından Türkiye genelinde 35. sırada yer almaktadır. Bu değer Tekirdağ İlinin sağlık sektöründe, ülke içerisinde oldukça alt seviyelerde yer aldığını gösterse de, bu durum Ill'in İstanbul'a yakınlığı ve İstanbul Metropoliten Bölgesi'nin içinde yer alması ve sağlık ihtiyaçlarının İstanbul'dan karşılandığı göz önünde bulundurularak değerlendirilmelidir.

Çizelge 6. Sosyo-Ekonomik Gelişmişlik Sıralaması (Kalkınma Bakanlığı, 2013)

\begin{tabular}{|l|c|c|}
\hline \multicolumn{1}{|c|}{ İ } & $\mathbf{2 0 0 3}$ & $\mathbf{2 0 1 1}$ \\
\hline Tekirdağ & 7 & 9 \\
\hline Edirne & 16 & 12 \\
\hline Kirklareli & 11 & 15 \\
\hline
\end{tabular}

Tekirdağ, gelişmiş sanayisi ve uluslararası firmaların içinde bulunduğu üretim tesisleriyle göz doldurmaktadır. Tekirdağ toplam işletmeler içerisinde \%2'lik payla sanayisi gelişmiş onuncu il olarak üst sıralarda yer almaktadır. Marmara Bölgesi dikkate alındığında \%3'lük sanayi payıyla İstanbul, Bursa ve Kocaeli'nden sonra dördüncü en büyük il olarak dikkat çekmektedir. Ülke genelinde tekstilin \% 10'u, margarinin \%25'i, rafine ayçiçeği yağının \%20'si, kağıt ve ambalajın \%40'1, işlenmiş derinin \%37'si bu ilden karşılanmaktadır. İldeki kuruluşlar kendi sektörlerinde marka konumda olan büyük işletmelerdir. 
Özellikle son yirmi yıl içerisindeki gelişmelerle birlikte Tekirdağ, adeta Türkiye'nin tekstil, gıda, toprak, beyaz eşya gibi alanlarda üretim üssü haline gelmiştir.

İl genelinde, Merkez, Çorlu, Çerkezköy, Hayrabolu ve Malkara'da olmak üzere 5 adet sanayi ve ticaret odası bulunmaktadır. Bu odaların kayıtlı üye sayısı 13 670'tir. Merkez, Çorlu, Hayrabolu ve Malkara' da bulunan dört adet ticaret borsasının da 389 faal üyesi bulunmaktadır.

Tekirdağ'da sektörlerin dağılımına bakıldığında 2011 verileri ilk sırada \%25 ile tekstil sektörüne işaret etmektedir. Bunu \%13 ile gıda ürünleri imalatı, \%7 ile giyim eşyası, kürkün boyanması ve işlenmesi, $\% 7$ ile makine ve teçhizat imalat1, \%5 ile diğer metalik olmayan ürünlerin imalatı, \%4 ile kauçuk ve plastik ürünler imalatı izlemektedir. Bunlar dikkat çeken ana kalemlerdir. Daha ayrıntıya girildiğinde, \%1-2'lere inen daha birçok sektör yer almaktadır. Söz konusu firmaların \%22'si mikro ölçekli, \%43’ü küçük ölçekli, \%29'u orta ölçekli, \%6'sı ise büyük ölçekli firmalardır.

Yeni kurulan şirketlerin toplam sermayelerinin yüzde 50'si İstanbul ve Ankara'da bulunurken on bin kişiye düşen yabancı sermayeli şirket sayısının en fazla olduğu iller Muğla, Antalya ve İstanbul'dur. Bu gösterge itibarıyla Gümüşhane, Kırıkkale, Bayburt, Bingöl, Bitlis ve Siirt illeri sıfıra yakın değerlere sahiptir. Yüz bin kişiye düşen marka başvuru sayısında İstanbul, Gaziantep ve Antalya, patent başvuru sayısında ise Manisa, Tekirdağ ve İstanbul ilk üç sırada bulunan illerdir.

Bu durum Ill'in bölgedeki diğer illere oranla, özellikle Marmara Ereğlisi, Çorlu ve Çerkezköy ilçelerinde sanayi faaliyetlerinin yüksek olmasından dolayı sektörel Gayri Safi Yurt İçi Hasıla (GSYIH) değerlerinin yüksek olmasından kaynaklanmakta, böylece kişi başı GSYIH değerleri de yüksek çıkmaktadır. Tekirdağ ilinde hakim sektör sanayi sektörüdür. İmalat sanayi, elektrik, gaz ve su sektörü, Ticaret sektörü toptan ve perakende ticaret oranının artışı bu değerlerin yüksek olmasına neden olmuştur.

\section{TARIM}

Tekirdağ'’n toplam yüzölçümünün 2/3' ü tarıma elverişli olup, yaklaşık 400.000 hektar alanın \% 47,1'i mutlak tarım arazisi, $\% 51,8$ 'i özel ürün ve $\% 1,1$ 'de dikili tarım arazisidir. Tekirdağ'da işlenen tarım alanlarının dağılımına bakıldı̆̆ında \% 96,33 ile tarla arazilerinin başı çektiği görülmektedir. Bunu \%1,30 ile sebze alanları, \%1,08 ile bağ arazileri, \%1,02 ile zeytinlik araziler ve \%0,27 ile de meyvelik araziler izlemektedir (Çizelge 7).

Çizelge 7. İşlenen Tarım Alanlarının Dağılımı (TÜIK, 2013c)

\begin{tabular}{|l|c|c|}
\hline \multicolumn{1}{|c|}{ Kullanılıș Şekli } & Alan (da) & Oranı (\%) \\
\hline Tarla Arazisi & 3.741 .539 & 96,33 \\
\hline Bağ Arazisi & 41.962 & 1,08 \\
\hline Sebze Arazisi & 50.569 & 1,30 \\
\hline Zeytinlik Arazi & 39.720 & 1,02 \\
\hline Meyvelik Arazi & 10.435 & 0,27 \\
\hline Toplam & 3.884 .225 & 100,00 \\
\hline
\end{tabular}

İlde yaklaşı 12.000 ha alanda entansif tarım yapılmaktadır. Tarım sektörü, il ekonomisinde sanayiden sonra ikinci sırada yer almaktadır. Türkiye üretiminin \% 35,9'u Tekirdağ'da üretilmektedir. Türkiye kolza üretiminin $\% 45,61$ ' i Tekirdağ ilinde yapılmaktadır. Bağcllık önemli üretim konularından biridir. İlin toplam bağ alanı 41.962 dekar olup, bağlardan 41.595 ton yaş üzüm elde edilmiştir. İlde üretimi yapılan 41.595 ton üzümün yaklaşık \% 70,1'ü şaraplık olup kalan kısmı ise sofralık olarak değerlendirilmektedir. İlçelere göre işlenen tarım alanlarının dağılımı Çizelge 8'de verilmiştir.

Çizelge 8. Tekirdağ İli İlçelere Göre İşlenen Tarım Alanlarının Dağılımı 


\begin{tabular}{|c|c|c|c|}
\hline İlçeler & Tarım Alanı (da) & Çayır-Mera(da) & Orman-Funda ve Diğer Araziler (ha) \\
\hline Merkez & 743.653 & 45.441 .11 & 165.290 \\
\hline Çerkezköy & 131.851 & $13.629,2$ & \multirow{3}{*}{101.440} \\
\hline Çorlu & 633.888 & 32.296 & \\
\hline Marmara Ereğlisi & 138479 & 3.903 & \\
\hline Hayrabolu & 580.993 & $97.968,9$ & 21.810 \\
\hline Malkara & 749.813 & $79.880,5$ & 223.885 \\
\hline Muratlı & 323.194 & $18.718,8$ & 3.880 \\
\hline Saray & 315.434 & $31.711,8$ & 268.720 \\
\hline Şarköy & 153.242 & 2.244 & 257.540 \\
\hline Toplam & 3.770 .547 & $325.793,41$ & 1.040 .860 \\
\hline
\end{tabular}

Kaynak: Tekirdağ İl Gıda Tarım Ve Hayvancılık Müdürlüğü, 2011: 34.

Çizelgeden de görüldüğü gibi en fazla tarım alanı sırası ile; Malkara, Merkez ve Çorlu ilçelerinde, çayırmera alanı; Hayrabolu, Malkara ve merkez ilçede, orman alanı ise Şarköy, Saray ve Malkara ilçelerinde bulunmaktadır.

Tarla bitkilerine bakıldığında, büyük çoğunluğu buğday, ayçiçeği ve silajlık mısır oluşturulduğu görülmektedir. Diğer ürünlere göre en az yetiştirilen tarla bitkisi de çeltik olarak göze çarpmaktadır (Çizelge 9).

Çizelge 9. Önemli Tarla Bitkileri Ekiliş Ve Üretimleri(TÜİK, 2013c)

\begin{tabular}{|l|c|c|c|}
\hline \multicolumn{1}{|c|}{ Ürünler (2013) } & Ekiliș (Da) & Ortalama Verim(Kg/Da) & Üretim(ton) \\
\hline Buğday & 1.683 .887 & 378 & 631.164 \\
\hline Ayçiçeği & 925.469 & 229 & 211.671 \\
\hline Arpa & 143.840 & 441 & 63.422 \\
\hline Silajlık Misır & 84.554 & 3.898 & 329.564 \\
\hline Fiğ(yeşil ot) & 29.290 & 1.906 & 55.828 \\
\hline Çeltik & 31.000 & 932 & 28.899 \\
\hline Kanola & 184.527 & 337 & 62.095 \\
\hline
\end{tabular}

İl tarım üretiminin küçük bir bölümünü oluşturan sebzecilik ele alındığında, bu üretimin büyük bölümünü karpuzun oluşturduğu görülmektedir (Çizelge 10). Bu ürünü sırasıyla kavun, domates ve hıyar takip etmektedir. Tekirdağ' da kavun ve karpuzun dışında il dışı pazar için üretim yapılmamaktadır. Yetiştirilen sebzeler aile içi ve dahili pazara dönüktür.

Çizelge 10. Önemli Sebzelerin Ekiliş Ve Üretimleri(TÜIK, 2013c)

\begin{tabular}{|l|c|c|}
\hline \multicolumn{1}{|c|}{ Ürünler(2013) } & Ekiliș (Da) & Üretim(ton) \\
\hline Karpuz & 16.271 & 54.400 \\
\hline Kavun & 6.488 & 14.802 \\
\hline
\end{tabular}




\begin{tabular}{|l|c|c|}
\hline Domates (sofralık) & 2.020 & 7.533 \\
\hline Çerezlik Kabak & 1.087 & 121 \\
\hline Biber (sivri-çarliston) & 929 & 949 \\
\hline Hıyar(sofralık) & 927 & 2.763 \\
\hline Beyaz Lahana & 651 & 2.215 \\
\hline Bal Kabağı & 339 & 934 \\
\hline
\end{tabular}

İ tarım üretiminde meyvecilikte zeytin ve kirazın diğer ürünlere göre daha fazla yer kapladığ 1 görülmektedir. Bu ürünleri yine üzüm çeşitleri izlemektedir (Çizelge 11).

Çizelge 11. Önemli Meyvelerin Ekiliş Ve Üretimleri (TÜIK, 2013c)

\begin{tabular}{|l|c|c|c|}
\hline \multicolumn{1}{|c|}{ Ürünler(2013) } & Ekiliş (Da) & Üretim(ton) & Toplam Ăgaç Sayısı \\
\hline Kiraz & 2.369 & 2.441 & 113.916 \\
\hline Zeytin & 4.234 & 1.140 & 124.000 \\
\hline Üzüm Şaraplık & 24.700 & 18.934 & 24.700 \\
\hline Üzüm Çekirdekli & 12.698 & 12.365 & 12.698 \\
\hline
\end{tabular}

\section{7. İŞGÜCÜ DURUMU}

Tekirdağ bütününde 12 yaş ve üzeri yaştaki nüfusun içinde istihdam edilenler ve işsizlerin oluşturduğu işgücüne bakıldığında, işgücüne katılım oranının özellikle kadınlarda, tüm ilçe merkezlerinde düşük olduğu görülmektedir. Tarımsal üretimin devam ettiği Tekirdağ kırsalında işgücüne katılım oranı kadınlarda ve erkeklerde birbirine yakın ve yüksektir. Bunun yanında tarımsal üretimin yoğun olduğu ilçelerden Şarköy, Malkara ve Hayrabolu ilçe merkezlerinde kadınların işgücüne katılım oranı (\%12-\%13 arası) oldukça düşüktür. İl toplamında işgücüne katılım oranı erkeklerde\%78,2 ve kadınlarda \%46,6'dır. Bu durum, kırsal alanda erkeklerde $\% 87,8$ ve kadınlarda \%84,8 işgücüne katılım oranının görülmesinden kaynaklanmaktadır. İşiz sayısı ise en yüksek Tekirdağ Merkez, Çorlu ve Çerkezköy ilçelerinde görülmektedir. Bunun sebebi burada sanayi ve hizmetler sektörünün İl'in diğer bölgelerine oranla yüksek olması ve bu bölgelerde sağlanan istihdamdan fazla göç almasıyla ilişskilidir.

\section{KENTIN MEKANSAL GELIŞiMi}

1/100.000 ölçekli Trakya Alt Bölgesi Ergene Havzası Revizyon Çevre Düzeni Planı'nda TR21 Trakya Bölgesinde kademeli merkez yerleşimler beş grupta kurgulanmıştır. Bu çerçevede; III. ve IV. Kademe Kentsel Merkezler "orta merkez" karakteri taşımaktadır. Bu grupta, sanayi üretimine olduğu kadar tarımsal sanayi türünde faaliyet gösteren merkezler de olabilmektedir. V. Kademe Kentsel Merkezler ise, temelde kırsal alanlara kentsel hizmetler vermek üzere donatılacak "alt merkez" karakteri taşıyan yerleşimlerdir. Burada önemli olan, önerilen merkezlerin Tekirdağ merkezli yığılmayı Bölge geneline dağıtması ve kır-kent arası kutuplaşma gidermesine yönelik beklentidir. Merkez kademelenmesinde, Tekirdağ ili I. derece merkez kademesinde bir hizmet merkezi olarak öngörülmektedir. Fakat Bölge genelinde bugüne kadar süregelen Tekirdağ merkezli gelişmenin dengeli dağılabilmesi için, Edirne, Kırklareli il merkezleri ve Keşan, Lüleburgaz, Çorlu, Çerkezköy ilçeleri II. Kademe Merkez olarak geliştirilecektir. 
Çerkezköy, Tekirdağ'ın İstanbul'a en yakın bölgesidir. Tekirdağ kalkınmada öncelikli yöre olarak ilan edilerek geri kalmış yörelere uygulanan teşvik tedbirlerinden yararlanmaya başlayınca, İstanbul'daki yeni sanayilerin hızla Çerkezköy’e yığılmaya başladığı görülmüştür. Özellikle Bölge içinde Edirne'nin 1969, 1972 ve 1973 Program Kararnamesi ile "Kalkınmada Öncelikli Yöreler" kapsamına alınması ve Tekirdağ'ın 1977 yılında kalkınmada öncelikli yörelere dahil edilmesi sanayileşme sürecini tetiklemiştir. Bu gelişmelerin yanı sıra 1970'li yılların basında İstanbul sanayisinin desantralizasyonu amacına yönelik yer arama çabaları, en yakın bölge olan Trakya'ya yönelerek sonuçlanmıştır. Nitekim 1973 yılında Çerkezköy Organize Sanayi Bölgesi'nin kurulması ile birlikte Çerkezköy ve Çorlu ilçelerinde hızla gelişmeye başlayan sanayileşme, 1980'li yıllardan sonra Muratlı ilçesini de kapsayacak şekilde genişlemiştir. Bölgede bulunan sanayi işletmelerinin önemli bir bölümü Çorlu, Çerkezköy, Lüleburgaz ve Muratlı ilçelerindedir.

Tekirdağ ilinin Çorlu ve Marmara Ereğlisi ilçelerinde, diğer ilçelere oranla daha fazla konut alanı bulunmaktadır. Çorlu'da konut alanlarının fazla olması; sanayi ve bunu takiben hizmet faaliyetlerinin yoğun olmasından dolayı nüfus değerinin de yüksek olmasından kaynaklanmaktadır. Marmara Ereğlisi'nde ise, bu durumun sebebi, ikinci konutların yoğun olmasından dolayı az yoğun olan, dikey değil yatay gelişim sergileyen bir yerleşim yapısına sahip olmasıdır.

Marmara Ereğlisi'ne ek olarak, Şarköy ve Tekirdağ Merkez ilçeleri de deniz kıyısında yer aldıkları için ikinci konutların yoğun olduğu ilçelerdir. Tekirdağ Merkez ilçede özellikle Kumbağ ve Barbaros beldeleri ile Merkez ilçede bu oran yüksektir. İl bütününe bakıldığında, sanayi faaliyetlerinin yoğun olduğu ilçelerde belde statüsüne sahip yerleşmelerin konut alanlarının, tarımsal üretimin yoğun olduğu ilçelere oranla daha fazla olduğu görülmektedir. Tarımsal üretimin yoğun olarak görüldüğü ilçelerde ise köy yerleşmeleri daha büyüktür. İlçelerdeki istihdam türünün insanların yaşadığı yerleri etkilediği görülmektedir. Örneğin Çorlu, Çerkezköy, Tekirdağ Merkez ve Marmara Ereğlisi ilçelerindeki konut alanları, Hayrabolu, Malkara, Saray, Şarköy ve Muratlı gibi tarımsal odaklı ilçelerden fazladır. Sanayi tesisleri Tekirdağ ilindeki bazı yerleşim yerlerinde o bölgenin kaynaklarından faydalanmak üzere münferit olarak yayılmış olsa da genellikle belirli akslar üzerinde yoğunlaşmıştır. Bu aksların en yoğun olanları (Anonim, 2010);

- Çorlu - Velimeşe - Veliköy - Çerkezköy,

- Çorlu - Marmaracık - Ulaş - Vakıflar - Misinli - Büyükkarıştıran - Lüleburgaz,

• Çorlu - Türkgücü Köyü,

- Çorlu - Tekirdağ Yolu ve

- Büyükkarıştıran - Muratlı arasıdır.

\section{TARIHİ GELIŞSiM}

Tekirdağ, Roma döneminde, İS. 3. Yüzyılda Rhaedestus ismi ile tarih sahnesine çıkmış olup, Bizans döneminde "Bisaltia ve Rodosto" ismi ile anılmıştır. Bisaltia bölgesinin güneyinde yani Marmara Denizi kıyılarının kuzey-batı bölümüne (bugünkü Tekirdağ ve çevresi) ise Biston Trakları oturmaktadır. 16. yüzyıl Tekirdağ'ın antik dönem kaynaklarında bilinen ilk isminin Visanthe ya da Bisanthe olması bu ismin bölgede yaşayan Biston Traklarına istinaden verilmiş olduğunu göstermektedir. Osmanlılar 14. yüzyılda Tekirdağ'1 Bizans Tekfurundan aldıktan sonra, Rodosto adı Rodosçuk'a dönüşmüştür. 1354-1357 yıllarından sonra Rodoscuk adıyla Gelibolu Sancağı'na bağlı bir kaza merkezi haline getirilmiştir. 18. yüzyıla kadar bu isimle anılan Rodosçuk, sonradan Bizans tekfurları tarafından verildiği öne sürülen 'Tekfurdağ" adıyla anılmaya başlanmıştır. Osmanlı Devleti'nin klasik döneminde, Tekfurdağ'ın Rumeli Eyaleti'nin Çirmen Livası' na, Çorlu ve Hayrabolu'nun ise Vize Livası'na bağlı olduğu belirtilmektedir. 1831 Osmanlı nüfus sayımı kayıtları, Tekfurdağı'nı Silistre Eyaleti içinde göstermektedir. 1847'deki yönetim teşkilatlanmasında, Edirne Eyaleti, Merkez, Vize, Gelibolu ve Filibe livalarından oluşmakta, 1867 Vilayet Nizamnamesi'ne göre Edirne Vilayeti'nin Merkez, Gelibolu, Tekfurdağı, Filibe ve İslimiye olmak üzere toplam 5 sancağından biri konumunda yer almaktadır. Cumhuriyet'ten sonra bu yerleşim il olmuş ve Tekirdağ adını almıştır. 20 Ocak 
1921 tarihli Teşkilat-1 Esasiye Kanunu gereğince girişilen yeni örgütlenme sırasında Tekirdağ il olmuştur. Ancak, il merkezi Cumhuriyetin ilanından önce 15 Ekim 1923 tarihinde kurulmuştur.

\section{TEKIRDAĞ BELEDIYYESİ'NIN TARİHI GELIŞ̧IMI}

Tekirdağ'sa ilk belediye kuruluşu 1879 yılında olmuş, ilk Belediye Başkanı da tarihi kayıtlara göre Hasan Cemali Baba'dır. Müstakil ilk Belediye binası olarak kullanılmış olan tarihi bina 1901 yılında Belediye Başkanı Avukat Adil Bey zamanında Paris Belediye binası örnek alınıp küçültülmüşs şekli ile inşa edilmiştir. Cumhuriyet döneminden önce, 1879-1893 yılları arasında 9, Cumhuriyet döneminde 1923-2014 yılları arasında 30 belediye başkanı görev yapmıştır. 2014 yerel seçimlerinden sonra Büyükşehir statüsündeki Tekirdağ Büyükşehir Belediyesi 60 üye ile temsil edilmektedir.

\section{BÜYÜKŞEHİR OLMA SÜRECİ ve BÜYÜKŞEHİR OLDUKTAN SONRAKİ DURUM}

Tekirdağ, 6 Aralık 2012 Tarihli ve 28489 Sayılı Resmî Gazete yayımlanarak yürürlüğe giren 6360 sayılı "On Üç İlde Büyükşehir Belediyesi ve Yirmi Altı İlçe Kurulması ile Bazı Kanun ve Kanun Hükmünde Kararnamelerde Değişiklik Yapılmasına Dair Kanun” doğrultusunda Büyükşsehir olmuştur (Resmi Gazete, 2012: 11741).Bu kanun kapsamında;

- Tekirdağ İlinde, Tekirdağ Belediyesinin mahalleleri merkez olmak üzere, Tekirdağ Merkez ilçe sınırları içerisindeki köyler ile belediyelerden oluşan Süleymanpaşa İlçesi ve aynı adla belediye kurulmuştur.

- Tekirdağ İlinde, Kapaklı Belediyesi merkez olmak üzere Kapaklı ilçesi ve aynı adla belediye kurulmuştur.

- Tekirdağ İlinde, Marmaracık Belediyesi merkez olmak üzere Çorlu Belediyesinin mahalleleri ile köyler ve belediyelerden oluşan Ergene İlçesi ve aynı adla belediye kurulmuştur.

- İl Özel İdaresi kaldırılmıştır.

Öncelikli olarak ilçe bazında bakılacak olursa, yukarıda da belirtildiği gibi Tekirdağ İli büyükşehir olmadan önce 9 ilçeye sahipken, büyükşehir olduktan sonra ilçe sayısı 11'e yükselerek idari sınırları belirlenmiştir (Şekil 1). 


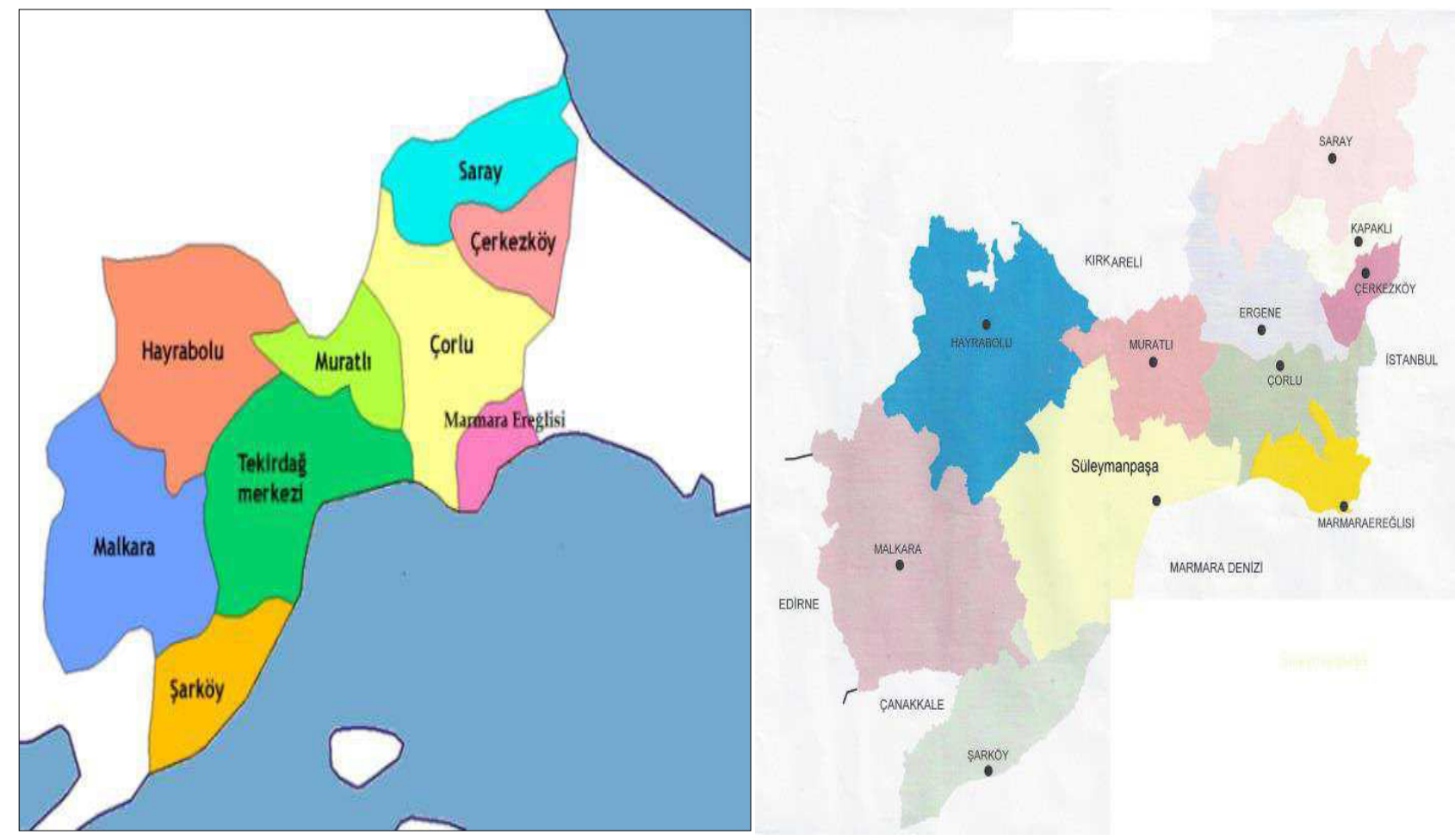

Şekil 1. Tekirdağ İlinin büyükşehir olmadan önce ve olduktan sonraki ilçe sayısı

İlçe sınırlarındaki değişime bakıldığında, Süleymanpaşa, Ergene ve Kapaklı ilçeleri yeni kurulmuştur. Genel itibarı ile büyükşehir olmadan önce bulunan Merkez ilçe Süleymanpaşa İlçesi'ne dönüştürülmüştür. Çorlu İlçesi'ne ait olan bazı mahalleler yeni kurulan Ergene İlçesi'ne bağlanmıştır (Çizelge 12). Çerkezköy İlçesi'ne bağlı bazı mahallelerde yeni kurulan Kapaklı ilçesine bağlanarak idari ilçe sinırları tekrar belirlenmiştir (Çizelge 13).

Çizelge 12. Tekirdağ İli Ergene İlçesine Bağlanan Belediyeler ve Köyler (Resmi Gazete, 2012: 11741)

\begin{tabular}{|l|l|l|l|}
\hline Sıra & Birimin Adı & İlçesi & Bağlı Olduğu Bucak \\
\hline $\mathbf{1}$ & Ulaş Belediyesi & Çorlu & Merkez \\
\hline $\mathbf{2}$ & Misinli Belediyesi & Çorlu & Merkez \\
\hline $\mathbf{3}$ & Velimeşe Belediyesi & Çorlu & Merkez \\
\hline $\mathbf{4}$ & Paşaköy & Çorlu & Merkez \\
\hline $\mathbf{5}$ & Pınarbaş1 & Çorlu & Merkez \\
\hline $\mathbf{6}$ & Ahimehmet & Çorlu & Merkez \\
\hline $\mathbf{7}$ & İğneler & Çorlu & Merkez \\
\hline $\mathbf{8}$ & Vakıflar & Çorlu & Merkez \\
\hline $\mathbf{9}$ & Esenler & Çorlu & Merkez \\
\hline $\mathbf{1 0}$ & Kırkgöz & Çorlu & Merkez \\
\hline $\mathbf{1 1}$ & Bakırca & Çorlu & Merkez \\
\hline
\end{tabular}




\begin{tabular}{|l|l|l|l|}
\hline $\mathbf{1 2}$ & Karamehmet & Çorlu & Merkez \\
\hline $\mathbf{1 3}$ & Yulaflı & Çorlu & Merkez \\
\hline
\end{tabular}

Çizelge 13.Tekirdağ İli Kapaklı İlçesine Bağlanan Belediye Ve Köyler (Resmi Gazete, 2012: 11741)

\begin{tabular}{|l|l|l|l|}
\hline Sıra & Birimin Adı & İlçesi & Bağlı Olduğu Bucak \\
\hline $\mathbf{1}$ & Karaağaç Belediyesi & Çerkezköy & Merkez \\
\hline $\mathbf{2}$ & Bahçeağıl & Çerkezköy & Merkez \\
\hline $\mathbf{3}$ & Yanıkağıl & Çerkezköy & Merkez \\
\hline $\mathbf{4}$ & Karlı & Çerkezköy & Merkez \\
\hline $\mathbf{5}$ & Pinarca & Çerkezköy & Merkez \\
\hline $\mathbf{6}$ & Uzunhacı & Çerkezköy & Merkez \\
\hline
\end{tabular}

Büyükşehir olma süreci ile yeniden şekillenen bucaklar ve bağlı oldukları ilçeler Çizelge 14, belde belediyeler Çizelge 15 ve köyler ise Çizelge 16 'da verilmiştir.

Çizelge 14. Bucakların Listesi (Resmi Gazete, 2012: 11741)

\begin{tabular}{|c|c|c|}
\hline Bucak Adı & İlçe Adı & İl adı \\
\hline Merkez & Çerkezköy & Tekirdağ \\
\hline Merkez & Çorlu & Tekirdağ \\
\hline Merkez & Ergene & Tekirdağ \\
\hline Dambaslar & Hayrabolu & Tekirdağ \\
\hline Merkez & Hayrabolu & Tekirdağ \\
\hline Susuzmüsellim & Hayrabolu & Tekirdağ \\
\hline Merkez & Kapaklı & Tekirda $\breve{g}$ \\
\hline Ballı & Malkara & Tekirdağ \\
\hline Merkez & Malkara & Tekirdağ \\
\hline Şahin & Malkara & Tekirdağ \\
\hline Yürük & Malkara & Tekirdağ \\
\hline Merkez & Marmaraereğlisi & Tekirdağ \\
\hline Merkez & Muratlı & Tekirdağ \\
\hline Beyazköy & Saray & Tekirda $\breve{g}$ \\
\hline Merkez & Saray & Tekirdağ \\
\hline Merkez & Süleymanpaşa & Tekirdağ \\
\hline Merkez & Şarköy & Tekirdağ \\
\hline Mürefte & Șarköy & Tekirdă \\
\hline
\end{tabular}

Çizelge 15. Belde Belediyelerinin Listesi (Resmi Gazete, 2012: 11741) 


\begin{tabular}{|c|c|c|}
\hline \multicolumn{2}{|l|}{ Adı } & \multirow{2}{*}{$\begin{array}{l}\text { Bağlı olduğu Belediye } \\
\text { Malkara }\end{array}$} \\
\hline Balabancık & Ballı & \\
\hline Banarlı-bucak merkezi & Merkez & Süleymanpaşa \\
\hline Barbaros-bucak merkezi & Merkez & Süleymanpaşa \\
\hline Beyazköy-bucak merkezi & Beyazköy & Saray \\
\hline Büyükyoncalı & Merkez & Saray \\
\hline Çerkezmüsellim & Merkez & Hayrabolu \\
\hline Ergene & Merkez & Çorlu \\
\hline Hoşköy & Mürefte & Şarköy \\
\hline Kapaklı & Merkez & Çerkezköy \\
\hline Karaağaç & Merkez & Kapaklı \\
\hline Karacakılavuz & Merkez & Süleymanpaşa \\
\hline Kizılpınar & Merkez & Çerkezköy \\
\hline Kozyürük & Şahin & Malkara \\
\hline Kumbağ & Merkez & Süleymanpaşa \\
\hline Misinli & Merkez & Ergene \\
\hline Mürefte-bucak merkezi & Mürefte & Şarköy \\
\hline Sağlamtaş & Ball1 & Malkara \\
\hline Sultanköy & Merkez & Marmaraereğlisi \\
\hline Şalgamlı & Susuzmüsellim & Hayrabolu \\
\hline Ulaş & Merkez & Ergene \\
\hline Veliköy & Merkez & Çerkezköy \\
\hline Velimeşe & Merkez & Ergene \\
\hline Yenice & Merkez & Çorlu \\
\hline Yeniçiftlik & Merkez & Marmaraereğlisi \\
\hline
\end{tabular}

Çizelge 16. Köy Listesi (Resmi Gazete, 2012: 11741)

\begin{tabular}{|l|l|}
\hline İlçe & Köy Sayısı \\
\hline Çorlu & 7 \\
\hline Süleymanpaşa & 55 \\
\hline Çerkezköy & - \\
\hline Kapaklı & 6 \\
\hline Ergene & 10 \\
\hline Malkara & 70 \\
\hline Saray & 19 \\
\hline Hayrabolu & 46 \\
\hline
\end{tabular}




\begin{tabular}{|l|l|}
\hline Şarköy & 26 \\
\hline Muratlı & 16 \\
\hline Marmara Ereğlisi & 3 \\
\hline
\end{tabular}

Büyükşehir olma sürecinde yeniden yapılanmaya bağlı olarak, 2012 ve 2013 yılları ilçe merkezleri nüfuslarında da değişimler olmuştur (Çizelge 17, Çizelge 18). Özellikle Çorlu ve Çerkezköy'ün bazı yerleşimlerinin yeni kurulan ilçeler Ergene ve Kapaklıya bağlanması ile bu ilçelerde 2012 yılına oranla nüfusun azaldığı görülmektedir. Bunun asıl nedeni nüfusun yeni belediyelere aktarılmış olmasıdır.

Çizelge 17. 2012 Yılı İl Ve İlçe Nüfusları (TÜIKK, 2012)

\begin{tabular}{|l|l|l|l|}
\hline İlçeler & Erkek Nüfus & Kadın Nüfus & $\begin{array}{l}\text { Toplam } \\
\text { Nüfus }\end{array}$ \\
\hline Çorlu & 140.733 & 132.629 & 273.362 \\
\hline Merkez & 90.594 & 86.254 & 176.848 \\
\hline Çerkezköy & 98.336 & 90.376 & 188.712 \\
\hline Malkara & 27.804 & 26.317 & 54.121 \\
\hline Saray & 23.855 & 23.144 & 46.999 \\
\hline Hayrabolu & 17.903 & 16.575 & 34.478 \\
\hline Şarköy & 15.116 & 14.875 & 29.991 \\
\hline Muratlı & 13.456 & 12.885 & 26.341 \\
\hline Marmara Ereğlisi & 1.327 & 10.142 & 21.469 \\
\hline
\end{tabular}

Çizelge 18. 2013 Yılı İl Ve İlçe Nüfusları (TÜİK, 2013a)

\begin{tabular}{|l|l|l|l|}
\hline İlçeler & Erkek Nüfus & Kadın Nüfus & $\begin{array}{l}\text { Toplam } \\
\text { Nüfus }\end{array}$ \\
\hline Çorlu & 115.759 & 109.781 & $\mathbf{2 2 5 . 5 4 0}$ \\
\hline Süleymanpaşa & 91.534 & 87.705 & 179.239 \\
\hline Çerkezköy & 59.110 & 54.024 & $\mathbf{1 1 3 . 1 3 4}$ \\
\hline Kapaklı & 44.740 & 41.158 & 85.898 \\
\hline Ergene & 29.357 & 27.430 & 56.787 \\
\hline Malkara & 27.194 & 26.099 & 53.293 \\
\hline Saray & 24.064 & 23.107 & 47.171 \\
\hline Hayrabolu & 17.552 & 16.287 & 33.839 \\
\hline Şarköy & 15.141 & 14.853 & 29.994 \\
\hline Muratlı & 13.780 & 12.984 & 26.764 \\
\hline Marmara Ereğlisi & 11.918 & 10.898 & 22.816 \\
\hline
\end{tabular}




\section{BÜYÜKŞEHİR OLMUŞ İLLER İLE KARŞILAŞTIRILMASI}

Büyükşehir yönetimini tanzim eden yasaya göre bir ilin büyükşehir yönetimi altına alınması kararlaştırılırken göz önünde bulundurulan göstergelerden birisi de o ilin soysa-ekonomik gelişmişlik düzeyi ve yaşam kalitesi standartlarıdır. Bu bölümde, 6360 sayılı kanunla büyükşehir olan iller ve Tekirdağ'ın verileri üzerinden karşılaştırmalar yapılmıştır.

İllerin gelişmişlik sıralamaları dikkate alındığında büyükşehir yönetimine aday iller arasında Tekirdağ 2003 yilında en gelişmiş il olarak dikkat çekmektedir. 81 il arasında 7. olan Tekirdağ, gelişmişlik seviyesiyle diğer iller arasında kolaylıkla sıyrılmaktadır (Çizelge 19). Sıralamanın üst bölgelerine doğru tırmanmasında, ildeki aktif sanayi varlığı, üretim kapasitesi ve nitelikli insan gücü önemli rol oynamaktadır.

Çizelge 19. İllerin gelişmişlik seviyeleri (büyükşehir olmuş aday iller)

\begin{tabular}{|l|c|}
\hline İl & $\mathbf{8 1}$ ì İçinde Gelişmişlik Surası \\
\hline Tekirdağ & 7 \\
\hline Denizli & 12 \\
\hline Muğla & 13 \\
\hline Balıkesir & 15 \\
\hline Aydın & 22 \\
\hline Manisa & 25 \\
\hline Hatay & 29 \\
\hline Trabzon & 38 \\
\hline Malatya & 41 \\
\hline Kahramanmaraş & 48 \\
\hline Şanlıurfa & 68 \\
\hline Mardin & 72 \\
\hline Van & 75 \\
\hline
\end{tabular}

On üç ildeki kilometre kareye düşen kişi sayılarına bakıldığında, Tekirdağ 131 kişi ile Denizli ve Muğla'nın hemen ardından 3. sırada bulunmaktadır (Çizelge 20 ). Bu rakam Denizli'de 253, Muğla'da 162, Tekirdağ'ın hemen ardından gelen Aydın'da ise 102'dir. Dolayısıyla Tekirdağ diğer adaylarla mukayese edildiğinde kalabalık bir yerleşim alanı olarak kabul edilebilir. Burada, son yirmi yıl içerisinde ilin aldığı göçün de önemli bir payının olduğu unutulmamalıdır. Bilindiği üzere Tekirdağ iller arasında en çok net göç alan il olarak listenin ilk sirasında yer almaktadır.

Çizelge 20. İllerde $\mathrm{km}^{2}$ ye düşen kişi sayısı (TÜiK, 2013c)

\begin{tabular}{|l|c|}
\hline \multicolumn{1}{l}{ Çizelge 20. Illerde $\mathrm{km}^{2}$ ye düşen kişi sayısı (TÜiK, 2013c) } \\
\hline Tekirdağ & $\begin{array}{c}\mathbf{8 1} \text { İ İçinde } \mathbf{k m}^{2} \text { ye düşen insan } \\
\text { sayısı }\end{array}$ \\
\hline Denizli & 131 \\
\hline Muğla & 253 \\
\hline Balıkesir & 162 \\
\hline Aydın & 127 \\
\hline
\end{tabular}




\begin{tabular}{|l|c|}
\hline Manisa & 91 \\
\hline Hatay & 87 \\
\hline Trabzon & 81 \\
\hline Malatya & 81 \\
\hline Kahramanmaraş & 73 \\
\hline Şanlıurfa & 65 \\
\hline Mardin & 64 \\
\hline Van & 53 \\
\hline
\end{tabular}

Bir bölgenin gelişmişlik seviyesini tespit etmede, bölgede faaliyet gösteren kültür ve sanat aktivitelerinin yoğunluğu ve etkinliği oldukça önemlidir. İnsanların sinema, tiyatro, konser ve sergi gibi sanat faaliyetlerine olan ilgisi, bu olanakların şehirde yaşayanlara yakınlığı ve buna uygun faaliyet alanlarının kamu tarafindan hizmete sunulmuş olması kentte yaşamanın karakteristik özellikleri hakkında ipucu vermektedir.

Kültür-sanat verileri dikkate alındığında büyükşehir yönetimine geçen on iki il arasında Muğla, Aydın, Denizli ve Balıkesir gibi Ege Bölgesi ve çevresinde yer alan iller öne çıkmaktadır. Buralarda faaliyet rakamları diğer illerin önüne geçmektedir. Diğer taraftan, Van, Mardin ve Şanlıurfa gibi ülkenin doğu tarafında yer alan iller göreceli olarak bu faaliyet alanlarından daha az yararlanmaktadır. Tekirdağ, bu iki uç arasında ortalarda yer alırken, bazı aktivite alanlarında batı illerine, bazı aktivite alanlarında da doğu illerine benzerlik göstermektedir. Örneğin, TUİK rakamlarına göre 2010 yılında Tekirdağ'da kütüphane sayısı 9 iken, aynı yıl bu sayı Mardin'de 8, Van'da ise 10'dur. Ancak, kütüphane sayısı Denizli'de 27, Balıkesir'de 23 ve Aydın'da 18'dir. Tekirdağ'da bin kişiden 148'i bu kütüphanelerden yararlanırken, bu rakam Van'da 91, Denizli'de 548'dir. Sinema gösterim sayılarına bakıldığında ise Tekirdağ yine vasatın üstüne çıkamamıştır. Tekirdağ'da 2010 yılında 328 gösterim yapılmış ve on iki il arasında Tekirdağ bu sayı ile en çok gösterim yapılan 8. il olmuştur. Diğer veriler bu sıralamalar ile benzerlik göstermekte, çoğu alanda Tekirdağ açısından parlak bir sonuç ortaya koyamamaktadır.

On üç ili içeren ulaşım verileri içerisinde illerin yol uzunlukları, iniş-kalkış yapan uçak sayıları, seyahat eden uçak yolcusu sayıları ve bin kişi başına düşen otomobil sayıları dikkate alınmıştır. Tekirdağ'da devlet yolu uzunluğu $639 \mathrm{~km}$, köy yolu uzunluğu $1.702 \mathrm{~km}$ 'dir. Bin kişi içerisinde 91 kişi otomobil sahibiyken, iniş kalkış yapan uçak sayısı 20.252'dir (Çizelge 21). 2010 yılında ilde toplam 74.404 yolcu (iç ve diş hatlar) uçak ile yolculuk yapmıştır. Uçuş verilerinde Tekirdağ'ın zayıf kalmasının nedeni, ilde bulunan Çorlu Havaalanı'nın uzun bir süre boyunca sadece kargo uçakları için kullanılması gösterilebilir.

Çizelge 21. Ulaşım verileri (büyükşehir olmaya aday iller (FINTURK, 2011)

\begin{tabular}{|l|l|l|l|l|l|l|}
\hline İl & $\begin{array}{l}\text { İl ve Devlet Yolu } \\
\text { Uzunlukları } \\
(\mathbf{k m})\end{array}$ & $\begin{array}{l}\text { Köy Yolu } \\
(\mathbf{k m})\end{array}$ & $\begin{array}{l}\text { Bin } \\
\text { Başına } \\
\text { Otomobil } \\
\text { Sayısı }\end{array}$ & $\begin{array}{l}\text { İniş Kalkış } \\
\text { yapan } \\
\text { Sayısı }\end{array}$ & $\begin{array}{l}\text { İ̧̧ ve Dıs Hatlarda } \\
\text { Seyahat Yapan Yolcu } \\
\text { Sayısı }\end{array}$ \\
\hline Tekirdağ & 639 & 1702 & 91 & 20252 & 74404 \\
\hline Denizli & 826 & 4189 & 127 & 1754 & 135005 \\
\hline Muğla & 906 & 4229 & 149 & 52886 & 6870966 \\
\hline Balıkesir & 1241 & 5022 & 109 & 1033 & 37236 \\
\hline Aydın & 709 & 1436 & 109 & - & - \\
\hline
\end{tabular}




\begin{tabular}{|l|l|l|l|l|l|}
\hline Manisa & 1099 & 5388 & 92 & - & - \\
\hline Hatay & 636 & 2809 & 76 & 5573 & 574613 \\
\hline Trabzon & 843 & 12019 & 70 & 17795 & 1963169 \\
\hline Malatya & 1117 & 6301 & 69 & 5961 & 520457 \\
\hline Kahramanmaraş & 931 & 5061 & 69 & 675 & 51698 \\
\hline Şanluurfa & 1148 & 7458 & 45 & 2644 & 221034 \\
\hline Mardin & 761 & 4024 & 22 & 2839 & 305914 \\
\hline Van & 1121 & 5715 & 23 & 7923 & 892050 \\
\hline
\end{tabular}

\section{KENTIN BÜYÜKŞEHİR YAPILANMASINDAN SONRA YAŞANABİLECEK SORUNLAR ve ÇÖZÜM ÖNERILERI}

Yasal olarak büyükşehir olma sürecinin tamamlayan Tekirdağ İlinde uygulama süreçleri 30 Mart 2014 yerel seçimlerinden sonra başlamıştır. Her yeni statü değiştiren idari yapıda olduğu gibi Tekirdağ İli'nde de bu kısa süreçte göze çarpan en önemli sorun, Tekirdağ Büyükşehir Belediyesi ve yeni kurulan ilçe belediyelerinin idari ve fiziksel yapılarını oluşturmalarının ardından etkin biçimde çalışmalarının uzun bir süreç alacağı düşünülmektedir. Bu nedenle idari yapılanmanın bir an önce kurulması ve mevcut büyükşehir yasalarına uyarak il imar planlarının değiştirilerek tekrar güncellenmesi gerekmektedir.

\subsection{NÜFUS YOĞUNLUĞU-PLANSIZ YAPILAŞMA}

Uzun yıllar nüfus verileri incelendiğinde Tekirdağ sürekli göç alan bir yerleşimdir. Şöyle ki yapılan nüfus projeksiyonlarında 2023 y1lı için Tekirdağ'da beklenen nüfus 1.073.331'dir (Çizelge 22). Bu yapılan değerlendirme sonuçlarının büyükşehir olma süreci ile daha da artacağı düşünülürse, bu durumun ilin zaten plansız olan gelişimini daha da artıracağı düşünülmektedir. Bu da beraberinde tarım alanlarının ve yapay orman alanlarının yok olmasına, altyapının düzensiz gelişmesine ve yeterliliğini kaybetmesine sebep olacaktır. Tekirdağ mekânsal gelişim olarak İstanbul yönü (doğu)'ne doğru büyük bir gelişim içerisindedir. Yazlık konutların yoğun olarak yer aldığı bu kesimlerin ileride kışın da kullanılır hale gelmesiyle bu alanlardan bir takım katı atık sorunlarının ortaya çıkması buna bağlı olarak görüntü kirliliğinin ve hava kirliliğinin (kullanılan yakıt miktarının artması ve hava akımı sağlayacak sirkülasyon sistemlerinin olmaması) artmasina neden olacaktır.

Çizelge 22. 2013-2023 Arası Beklenen Nüfus Projeksiyonu

\begin{tabular}{|c|c|c|c|c|c|c|c|c|c|c|c|}
\hline Yll & 2013 & 2014 & 2015 & 2016 & 2017 & 2018 & 2019 & 2020 & 2021 & 2022 & 2023 \\
\hline Nüfus & 8728 & 893275 & 913614 & 933870 & 954049 & 974132 & 994121 & $\begin{array}{ll}1 & 014 \\
027\end{array}$ & $\begin{array}{l}1 \\
863\end{array}$ & $\begin{array}{l}1 \\
632\end{array}$ & $\begin{array}{ll}1 & 073 \\
331\end{array}$ \\
\hline
\end{tabular}

Birinci derece deprem bölgesinde bulunan ilde deprem açısından en riskli alanlar Marmara Denizi kıyılarında gelişen ve yılın büyük bir bölümü kullanılmayan ikincil konut alanlarıdır. Bu alanlar Büyükşehir olduktan sonra artan göç ve yerleşim yeri sıkıntısı ile birinci konuta dönüştürülmesi halinde zararlı ve/veya faydalı etkiler oluşabilecektir. Olumlu açıdan bu alanlar yıl boyu kullanılabilecektir. Ancak altyapı eksiklikleri nedeni ile özellikle deniz kirliliği açısından önemli bir potansiyel ortaya çıkabilecektir.

Tekirdağ İli koruma alanları bakımından oldukça zengindir (Çizelge 23). Koruncak alanlar ilin \% 91'lik kısmını oluşturmaktadır. Bu alanlarının en önemlisi tarımsal açıdan birinci öncelikli (mutlak) korunacak alanlardır. Büyükşehir olan Tekirdağ için bu alanlara baskının artacağı bir gerçektir. O nedenle yasal düzenlemelerin bir an önce yapılması önem arz etmektedir. 


\subsection{YEŞİL ALANLARIN AZALMASI}

Yıllık ortalama yağış miktarları ve ortalama yükseltisi düşük olan Tekirdağ, orman bakımından yoksul illerden biridir. En iyi ormanların Saray ilçesinin Bahçeköy çevresinde görüldüğ̈̈ İl'de meşe ormanları doğuda ve yer yer Tekir ve Koru Dağlarında görülmektedir. Ayrıca, bazı kesimlerde az miktarda Kızılağaç, Karaağaç ve yer yer de çam türleri bulunmaktadır. Tekirdağ ilindeki açık ve yeşil alanların birbirinden kopuk ve küçük parçalar halinde yerleşimler arasına dağılmış olduğu, kişi başına düşen yeşil alan miktarının yeterli olmadığı, fonksiyon ve estetik açıdan halkın ihtiyaçlarını karşılamadığı görülmektedir. Nüfusun hızlı artması ve çarpık kentleşme, Tekirdağ ilinde az olan açık ve yeşil alanların önemini daha da arttırmaktadır. Yeşil alanlar, toplam alan içinde yaklaşık \%0,5'lik bir paya sahiptir. Bu alanların tamamı merkezde ve kıyı bölgesinde yer almaktadır. Özellikle yeni yapılaşmaya açılan mahalle ve bölgelerde de imar planlarında yeşil alanlara yeteri kadar yer verilmemesi, bu alanlarında ileride kent merkezinin kalabalığına benzer özellik göstereceği bir gerçektir. Ayrıca yeni yapılan site ve konutlarda da bu tip yeşil alanlara büyük çoğunlukla yer verilmediği gözlenmektedir. Yeşil alanların önemli fonksiyonlarından biri olan hava kirliliğini absorbe etmesi özelliği, yetersiz yeşil alan miktarından dolayı yerine getirilememektedir. Bu da son yıllarda Tekirdağ'ın hava kirliliği bakımından iller sıralamasında üst sıralarda yer almasına sebep olmaktadır.

\begin{tabular}{|c|c|c|c|}
\hline \multicolumn{4}{|c}{ Çizelge 23. İldeki Koruma Alanları (Anonim, 2010) } \\
\hline \multirow{4}{*}{ Tekirdăg } & Arazi Kullanımı & Alan & $\%$ \\
\hline \multirow{4}{*}{$\begin{array}{c}\text { Orman Alanları } \\
\text { Klanları }\end{array}$} & $\begin{array}{c}\text { Ağaçlandırılacak Orman ile } \\
\text { Bütünleştirilecek Alanlar }\end{array}$ & 105.118 & 16.72 \\
\cline { 2 - 4 } & $\begin{array}{c}\text { Tarımsal Açıdan Birinci Öncelikli } \\
\text { (Mutlak) Korunacak Alanlar }\end{array}$ & 388.741 & 61.84 \\
\cline { 2 - 4 } & $\begin{array}{c}\text { Tarımsal Açıdan İkinci Öncelikli } \\
\text { Korunacak Alanlar }\end{array}$ & 12.317 & 1.96 \\
\cline { 2 - 4 } & Tarımsal Niteliği Sınırlı Alanlar & 23.466 & 3.73 \\
\cline { 2 - 4 } & Mera Alanları & 26.113 & 4.15 \\
\cline { 2 - 4 } & Baraj/Göl/Gölet & 6.385 & 1.02 \\
\cline { 2 - 4 } & Koruma Alanları Toplamı & 564.186 & 89.75 \\
\hline & Toplam Alan & 628.629 & 100.00 \\
\hline
\end{tabular}

Bununla beraber, açık ve yeşil alanlar afetlerde fonksiyonel olarak kullanılabilecek önemli boşluklar olarak değerlendirilmektedir. Özellikle Tekirdağ gibi deprem kuşağında yer alan illerde bu tip açık yeşil alanlar afet zamanlarında toplanma ve yerleşim alanları olarak değerlendirmek amacı ile önem taşımaktadır. Ancak mevcut durumda bu tip geniş açık ve yeşil alanlar ilde mevcut değildir.

İl genelinde yapılacak olan üst ölçekli planlardan başlayarak kent uygulama imar planlarına kadar her aşamada kentin açık yeşil alanları dikkate alınmalı ve miktarları arttırılmalıdır. Açık yeşil alanlar sadece imar fazlası küçük alanlar olarak değerlendirilmemelidir.

1/100.000 Ölçekli Trakya Alt Bölgesi Ergene Havzası Çevre Düzeni Planında da belirtilen; “2020 y1lını hedef alarak, Trakya Alt Bölgesi'nde sürdürülebilir, yaşanabilir bir çevre yaratılmasını; Alt Bölge'nin tarımsal, turistik ve tarihsel kimliğinin korunmasını ve Türkiye'nin kalkınma politikası kapsamında sektörel gelişme hedeflerine uygun olarak belirlenen planlama ilkeleri doğrultusunda sağlıklı gelişme ve büyümesini sağlamaktır” amacına uygun düzenlemelerin yapılmasını sağlamak önem taşmaktadır.

Plan'da, Çevre ve Orman Bakanlığı'nca orman kadastrosu yapılarak belirlenmiş alanlarla, orman özelliği gösteren alanlar; içme suyu, tarımda sulama amaçlı kullanılan ve kullanılması düşünülen gölet ve benzeri 
kaynaklar ve su toplama havzaları ve rezerv alanları; flora ve fauna açısından zengin, sulak alanlar, lagün gölleri vb. ekolojik açıdan eşsiz özellikler taşıyan alanlar, 2863 sayılı "Kültür ve Tabiat Varlıklarını Koruma Kanunu" uyarınca belirlenen ve belirlenecek olan sit alanları (kentsel, arkeolojik, doğal vb.); üzerinde yetişen özel ürünler açısından önem taşıyan özel mahsul alanları (zeytin, kestane, incir vb.) ve tarım toprakları ve fiilen sulanan ya da sulama projeleri ilgili kurum ve kuruluşlar tarafından hazırlanmış ve yatırım programlarına alınmış olan tarım alanlarının korunacağı belirtilmektedir. Tarım alanlarının korunmasının esas olduğu Plan kararlarına göre, kentsel ve kırsal yerleşmelerin gelişme alanlarının, tarım alanlarını yok etmeyecek şekilde koruma kullanma dengeleri gözetilerek geliştirileceği ifade edilmektedir. Ayrıca bu plana ilişsin;

Tekirdağ ilinde yer alan bataklık-sazlık-kamışlık-sulak alanlar ve kumullar, kumsallar, doğal plajlar, taşkın alanları, aktif heyelan bölgeleri ve depreme hassas bölgeler İl genelindeki doğal riskli alanları oluşturmaktadır (Çizelge 24 ).

Çizelge 24. Tekirdağ İli’nde doğal riskli alanlar (Anonim, 2010)
\begin{tabular}{|l|l|}
\hline Özel Önlem Gerektiren Alanlar & Alan (ha) \\
\hline Bataklık, Sazlık, Kamışlık, Sulak Alanlar & 36 \\
\hline Taşkın Alanı & 12.146 \\
\hline Aktif Heyelan Bölgeleri & 1.232 \\
\hline Depreme Hassas Bölgeler & 87.372 \\
\hline Kumullar, doğal plajlar, kumsallar & 97 \\
\hline Toplam & 100.883 \\
\hline
\end{tabular}

Bu alanlar içinde 87.732 ha. alan ile depreme hassas alanlar büyük yer kaplamaktadır. Özellikle bu alanlarda yapılaşamaya hiçbir şekilde izin verilmemesi gerekmektedir.

\section{3. ÇEVRE KİRLILİ̆́̇}

İstanbul Metropolü'ne ve önemli ulaşım akslarına yakınlığı nedeniyle İstanbul Metropolü’nden taşan sanayi kuruluşlarının buralarda yer seçmesi, Tekirdağ ilinde sanayi faaliyetlerinin gelişmesine neden olmaktadır. Özellikle büyükşehir olduktan sonra bu faaliyetlerin daha da artması beklenmektedir. Bunun sonucu olarak özellikle Trakya ve ülkemiz için önemli olan tarım alanların yok olma/tahrip olma sürecinin hızlanması beklenmektedir. Bu kullanımların en aza indirilmesi için mutlaka çalışmalar yapılması gerekmekte olup özellikle elverişli tarım topraklarının sadece tarımsal üretime ayrılması büyük önem taşımaktadır. Bununla beraber ilin ekonomisini oluşturan OSB'lerin zaten plansız olarak gelişmesi, dağınık ve organize olmayan bir şekilde yer seçmesi doğal yap1 üzerinde olumsuz etkiler yaratmaktadır. $\mathrm{Bu}$ plansızlık, ilin önemli bir potansiyeli olan doğal yapısı, zengin yeraltı kaynakları ve verimli tarım topraklarını olumsuz etkilemekte, Ergene Nehri'nin kirlenmesine sebep olmakta; Ergene Havzası'ndaki kirliliğin denetim altına alınamaması ise geri dönüşü zorlaştıran sonuçlar doğurmaktadır. Ayrıca, sanayi alanlarının plansız olarak gelişmesi ve buna bağlı olarak yapılan konut alanları nedeniyle ortaya çıkan altyapı eksikliklerinin İl açısından önemli bir sorun olduğu gözlenmektedir. Bu sorunların büyükşehir olduktan sonra daha da artması beklenmektedir

Tekirdağ il sınırları içerisinde bulunan konut, tesis ve işyerlerinde genellikle 1sınma amaçlı olarak kalorifer ve soba kullanılmaktadır. Kullanılan bu ısınma araçlarında doğalgaz, linyit kömürü ve odun yakılmaktadır. Tekirdağ ilinde yer alan konutların bazıları, yörede çıkarılan linyit kömürünün 1sı enerjisi ile 1sıtılmaktadır. Bu da Tekirdağ'ı kış aylarında yoğun bir hava kirliliğine maruz bırakan en önemli sebeplerdendir. Mevcut durumlarda hava kirliliğini önlemek için alınan baca filtreleri, kaliteli kömür kullanımı, düzenli ve kontrollü yakım vb. tedbirlerin uygulanması ile istenilen seviyede hava kirliliğinin 
azaltılması söz konusu olmadığından, hava kirliliğini önleyecek esas düzenleme ileriki yıllarda tüm konutların tamamen doğalgaz 1s1 enerjisine dönüştürülmesidir. Ancak, doğal gaz fiyatlarındaki artışlar geçim seviyesi düşük halkın odun ve kömür kullanımına sebep olmaktadır. Tekirdağ İl merkezi ve merkeze yakın yerleşim alanlarının doğalgaz enerjisi ihtiyacının karşılanmasına ait çalışmalar hızla devam etmekte olup Marmara Ereğlisi'nde bulunan BOTAŞ Doğalgaz Tesisleri'nden bu konuda hizmet alınmaktadır.

Trakya Alt Bölgesi'nde sanayi tesislerinin en fazla olduğu il olan Tekirdağ'da mevcut sanayi kuruluşlarının çoğunluğu ilçelere dağılmış olarak bulunmaktadır. Bu nedenle il merkezi hava kirliliğinden çok fazla etkilenmemektedir. Sanayi kuruluşları için ayrılmış olan sanayi bölgesinin yetersiz olması çarpık sanayileşmeyi beraberinde getirmiş ve tesis sayısının hızla artmasına yol açmıştır. Partiküler madde konsantrasyonları yıllara göre değerlendirildiğinde; 2006 yılı Kasım, Aralık, Ocak, Şubat ve Mart ayları içinde yüksek konsantrasyon değerleri ölçülmüştür. Özellikle Şubat ayı ortalaması $172 \mu \mathrm{g} / \mathrm{m}^{3}$ ve Aralık ayı ortalamas1 ise $168 \mu \mathrm{g} / \mathrm{m}^{3}$ 'tür. 2007 yılında en yüksek değer $164 \mu \mathrm{g} / \mathrm{m}^{3}$ ile Ocak ayı ortalamasıdır. Bu değerler, Hava Kalitesi Kontrol Yönetmeliği’nde belirtilen UVS sınır değerini aşmıştır.

Sanayi yoğunluğunun su kirliliği üzerindeki etkisi diğer tüm kirletici etkenlerden çok daha fazladır. Sanayilerden kaynaklanan atık suların arıtılmadan alıcı ortama verilmesi ile kirlenen sular hem ekolojik dengeyi bozmakta hem de daha sonra sulama suyu olarak kullanıldığında sudaki kirleticiler toprağa ve bitki örtüsüne zararlar vermektedir. Buna bağlı olarak hem su kaynakları kirlenip tükenmekte hem de canlı yaşamı tehlike altına girmektedir. Tekirdağ İli, Trakya Alt Bölgesi'nde sanayinin en çok geliştiği ildir. 1/100.000 Ölçekli Trakya Alt Bölgesi Ergene Havzası Çevre Düzeni Planı'nda Ergene Nehri kirliliğine en fazla katkının tekstil sektöründen geldiği görülmektedir. Yerüstü su kaynakları açısından Ergene Nehri ve kolları önemli bir yere sahiptir. Sanayi işletmelerinin atık sularını deşarj ettikleri atık su kanalı haline gelen Ergene Nehri ve kolları, bu nedenle yoğun bir kirlilik yükü taşımaktadır. Nehir fiziksel, kimyasal ve biyolojik özellikleri bakımından canlı yaşamı için uygun bir ortam olmaktan çıkmıştır. Trakya Alt Bölgesi'nde 11.325 $\mathrm{km}^{2}$ 'lik bir drenaj alanına sahip olan Ergene Havzası'nın sularını, doğudan batıya doğru akan Ergene Nehri drene etmektedir. Özellikle yer altı suyu kullanımının arttığı, dolayısıyla yeraltısuyu (YAS) seviyesinin düştügü yaz aylarında nehirdeki kirlilik çok üst seviyelere çıkmaktadır.

Tekirdağ İli iki ayrı denize kıyısı bulunan ve kıyı uzunluğu en fazla olan nadir illerden biridir. Karadeniz ile Akdeniz arasında bir iç deniz konumundaki Marmara Denizi’nin kuzey kıyısında doğuda Sultanköy Beldesi, batıda Şarköy İlçesi uç noktaları arasında, $135 \mathrm{~km}$ kıyı şeridine sahip olan İl, bu sebeple Marmara Denizi'nin bütün etkenleri ile içice bulunmaktadır. Bu doğrultuda Marmara Denizi'nin her türlü olumlu ve olumsuz sonuçları İl üzerinde etkili olmaktadır. İl nüfusunun bütün evsel atıkları direk deşarj ya da dereler yolu ile yıllardır denize akıtılmış, bu durumun önlenmesi çalışmaları ise ancak son yıllarda hız kazanmıştır. Tekirdağ İl Sağlık Müdürlüğü'nün yürüttüğü Mavi Bayrak Projesi kapsamında, Marmara Denizi kıyısında plaj özelliğinde 42 nokta seçilmiş ve bu noktalardan deniz suyu numuneleri alınarak analizleri yapılmıştır. Sonuçlara bakıldığında, mavi bayrak dikilebilmesi açısından Şarköy İlçesi'nde çalışmalar devam etmektedir. Ayrıca bu projenin İl'in Marmara Denizi'ne kıyısı olan diğer ilçeleri için de ilgili belediyeler ile çalışmalar yürütülmektedir. Deniz kirliliği, İl'in kıyısı olan bazı yerleşim yerlerindeki deniz canlılarının azalmasına yol açmaktadır. Bunun sonucunda deniz ürünleri işletmeleri kurulamamış, balıkçılık istenilen düzeyde gelişmemiştir. Marmara Denizi'nin bir diğer kirlenme nedeni transit geçiş yapan ya da liman ticareti nedeni ile kıyılarda seyreden gemilerin kaçak olarak boşalttıkları sintine sularıdır. Kimyasal kirlilik Marmara Denizi'nin ekolojik dengesini bozmaktadır.

Tekirdağ İli, birim alanda en çok gübre kullanılan illerdendir. Özellikle son yıllarda, bölgede bilinçsizce ve fazla miktarda gübre kullanıldığı dikkati çekmektedir. Tüketilen gübrelerin ürün grupları itibariyle dağılımına bakıldığında ise yaklaşık \%60’ının tahıl üretiminde tüketildiği görülür.

\section{SONUC}

2012 yılında onaylanarak yürürlüğe giren yasa ile birlikte 14 ilimiz büyükşehir statüsü kazanmıştır. Bu kentlerimiz, 2014 yerel seçimlerinden sonra fiziki ve idari yapılanmalarına resmi olarak başlamışlardır. Ancak büyükşehir olma süreci ve sonrasında bu kentlerimiz için çeşitli sorunlar ortaya çıkabilecektir. Bu sorunların en aza indirgenmesi için mevcut büyükşehirlerin fiziki ve idari yapılanmalarının detaylı bir 
şekilde incelenmesi gerekmektedir. Çünkü mevcut büyükşehirlerde yaşanan sorunlar, gerekli tedbir ve önlemler alınmaz ise yeni büyükşehirlerimiz içinde kaçınılmaz olacaktır. Özellikle, çarpık kentleşme, yeterli yeşil alanların olmayışı, nüfus artışı ve yetersiz altyapı bu kentlerimiz için önemli sorunlar olmaya devam etmektedir. $\mathrm{Bu}$ kapsamda büyükşehirlerin bazı yasal ve yönetsel mevzuatlara uyma zorunlulukları bulunmaktadır. Bunun yanında bu sorunları ortadan kaldırmaya veya en aza indirmeye yönelik yetkilere de sahiptir. Tekirdağ, bu yasa kapsamında büyükşehir olmuş Trakya (TR 21)'in tek kentidir. Kentin büyükşehir olma süreci incelendiğinde en büyük faktörün nüfus artış1 ve gelişmişliği olduğu belirlenmiştir. Bu süreç sonunda büyükşehir yapılanması hızlı bir şekilde devam etmektedir.

Tekirdağ konum itibarı ve bu zamana kadarki yönetim sürecinde kentleşme bakımından önemli sorunlar içindedir. Kent merkezindeki yoğunluğun azaltılamaması, kentsel planlama ve tasarım açısından eksiklikler, yeşil alanların hemen hemen hiç olmayışı, yetersiz altyapı ve üst yapı, yeni yerleşime açılan mahallerdeki çarpık yapılaşma (yetersiz yeşil alan ve ortak kullanımlar) birkaç örnektir ki, bunun sonuçlarını son yıllarda Tekirdağ'daki hava kirliliğin fazlalığı da büyük ölçüde ortaya koymaktadır. Bu tip çevresel zararlanmaların büyük çoğunluğunu kentin planlanmasındaki yanlış yaklaşımlar ve kentsel tasarım sürecindeki tasarımlar oluşturmaktadır.

Sonuç olarak, büyükşehir kapsamında yeni yapılacak planların üst ölçekli planlara uygun, dengeli bölgesel kalkınma stratejisine uyması gerekmektedir. Tekirdağ merkez dışındaki ilçelerinde potansiyelleri ve eğilimleri doğrultusunda mutlaka geliştirilmesi ve şehir merkezine olabilecek baskıların çevre ilçelere kaydırılması ile azaltılması gerekmektedir. Bu nedenle il ve ilçeler bazında kademelendirmeleri yapılmalı her bir kademe için geliştirme stratejileri belirlenmelidir. 


\section{KAYNAKÇA}

Anonim (2010). Tekirdağ İl Çevre Düzeni Planı (1/25000), Plan Analitik Raporu, İstanbul.

BİLIM, SANAYİ VE TEKNOLOJİ BAKANLIĞI (2012). 81 İ Durum Raporu, Ankara.

FINTURK (2011). Finansal Türkiye Haritası, Ankara.

KALKINMA BAKANLIĞI (2013). Illerin ve Bölgelerin Sosyo-Ekonomik Gelişmişlik Stralaması (SEGE2011), Bölgesel Gelişme ve Yapısal Uyum Genel Müdürlüğü, Ankara.

KARAYOLLARI GENEL MÜDÜRLÜĞÜ (2013) Tekirdă̆ İl-İlçe Uzaklıkları, Ankara.

RESMİ GAZETE (2012), On Dört İlde Büyükşehir Belediyesi ve Yirmi Yedi İlçe Kurulması İle Bazı Kanun ve Kanun Hükmünde Kararnamelerde Değişiklik Yapılmasına Dair Kanun, Ankara.

TEKIRDAĞ İL GIDA TARIM VE HAYVANCILIK MÜDÜRLÜĞÜ (2011). Tekirdağ Tarımsal Üretim Alanlarl, Tekirdağ.

TÜIK (2008). Gayri Safi Yurt İçi Hasıla, Ankara.

TÜIK (2011a). Tekirdă̆ Arazi Varlı̆̆g, Ankara.

TÜİK (2011b). Türkiye ve Tekirdăg dış ticaret verileri, Dış Ticaret İstatistikleri, Ankara.

TÜİK (2012). Tekirdağ İl ve İlçe Nüfusu, Adrese Dayalı Nüfus Kayıt Sistemi, Ankara.

TÜİ (2013a). Tekirdă̆ İl ve İlçe Nüfusu, Adrese Dayalı Nüfus Kayıt Sistemi, Ankara.

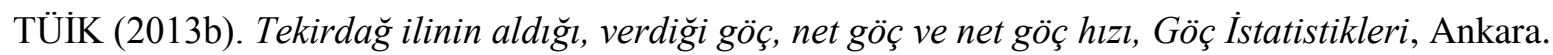

TÜİK (2013c). Tekirdă̆ İli Tarım Alanlarının Dağılımı, Tarımsal Alan İstatistikleri, Ankara. 